\title{
Extension in Mona Passage, Northeast Caribbean
}

\author{
Jason D. Chaytor*, Uri S. ten Brink \\ U.S. Geological Survey, Woods Hole Coastal and Marine Science Center, Woods Hole, MA 02543, USA
}

\section{A R T I C L E I N F O}

\section{Article history:}

Received 21 October 2009

Received in revised form 1 July 2010

Accepted 5 July 2010

Available online 15 July 2010

\section{Keywords:}

Bathymetry

Seismic reflection

Earthquakes

Oblique extension

Geomorphology

\begin{abstract}
A B S T R A C T
As shown by the recent $\mathrm{M}_{\mathrm{w}} 7.0$ Haiti earthquake, intra-arc deformation, which accompanies the subduction process, can present seismic and tsunami hazards to nearby islands. Spatially-limited diffuse tectonic deformation within the Northeast Caribbean Plate Boundary Zone likely led to the development of the submerged Mona Passage between Puerto Rico and the Dominican Republic. GPS geodetic data and a moderate to high level of seismicity indicate that extension within the region is ongoing. Newly-collected high-resolution multibeam bathymetry and multi-channel seismic reflection profiles and previouslycollected samples are used here to determine the tectonic evolution of the Mona Passage intra-arc region. The passage is floored almost completely by Oligocene-Pliocene carbonate platform strata, which have undergone submarine and subaerial erosion. Structurally, the passage is characterized by W- to NNWtrending normal faults that offset the entire thickness of the Oligo-Pliocene carbonate platform rocks. The orientation of these faults is compatible with the NE-oriented extension vector observed in GPS data. Fault geometry best fits an oblique extension model rather than previously proposed single-phase, poly-phase, bending-moment, or rotation extension models. The intersection of these generally NW-trending faults in Mona Passage with the N-S oriented faults of Mona Canyon may reflect differing responses of the brittle upper-crust, along an arc-forearc rheological boundary, to oblique subduction along the Puerto Rico trench. Several faults within the passage, if ruptured completely, are long enough to generate earthquakes with magnitudes on the order of $\mathrm{M}_{\mathrm{w}} 6.5-7$.
\end{abstract}

Published by Elsevier B.V.

\section{Introduction}

The January $12,2010 \mathrm{M}_{\mathrm{w}} 7.0$ Haiti earthquake provided a reminder of the considerable seismic hazard associated with intra-arc deformation within the northeast Caribbean plate boundary. Oblique subduction along this boundary zone is manifested in the development of a complex deformation environment, characterized by compressional, strike-slip, and extensional processes.

Mona Passage (in this paper we use the term Mona Passage in reference to the crust beneath the waters of the passage), located within the volcanically-inactive Greater Antilles arc between Puerto Rico and Hispaniola (Fig. 1), is an area of considerable shallow crustal earthquake activity. Seismicity is commonly characterized by small magnitude events, but the passage is also the site of the destructive 1918 earthquake and tsunami (Reid and Tabor, 1919; Lopez-Venegas et al., 2008). The passage has for some time been considered a region of extension resulting from oblique subduction along the northern Caribbean plate boundary. Published analyses of geodetic data from Hispaniola to the Virgin Islands show that extension in this region continues today, with Puerto Rico moving

\footnotetext{
* Corresponding author. Tel.: +1 508457 2351; fax: +1 5084572310. E-mail address: jchaytor@usgs.gov (J.D. Chaytor).
}

northeasterly away from Hispaniola at a rate of approximately $5 \pm$ $3 \mathrm{~mm} / \mathrm{yr}$ (Jansma and Mattioli, 2005).

Extensional deformation within compressive tectonic settings has been recognized as a common process along modern and ancient convergent margins worldwide. The causes of extension in these settings vary widely [see Doglioni (1995) for an overview], and include retreating subduction boundaries or roll-back (e.g., Royden, 1993), arc lengthening and increasing arc curvature (e.g., Wessel et al., 1994), lower plate bending at the subduction front (e.g., Chapple and Forsyth, 1979), and orogenic collapse (e.g., Dewey, 1988). Along subduction zones, extensional deformation is commonly observed within forearc and backarc regions, and in the down-going plate, but less often in the intra-arc zone (e.g., Geist et al., 1988; Mann and Burke, 1990; Suter et al., 1995; Busby and Bassett, 2007).

Intra-arc extension in Mona Passage is spatially-limited to a 100$\mathrm{km}$-long segment of the arc, and does not affect the entire arc as in the above examples. The driving force for this extension is therefore likely to be local. Several hypotheses for the formation of Mona Passage based predominantly on widely-spaced seismic reflection profiles have been proposed including single-phase extension across the plate boundary (e.g., Vogt et al., 1976; Speed and Larue, 1991), extension due to counter-clockwise rotation of Puerto Rico (e.g., Schell and Tarr, 1978; Masson and Scanlon, 1991; Mann et al., 2005a), poly-phase extension due to rotating axis of tensile stresses (e.g., Hippolyte et al., 

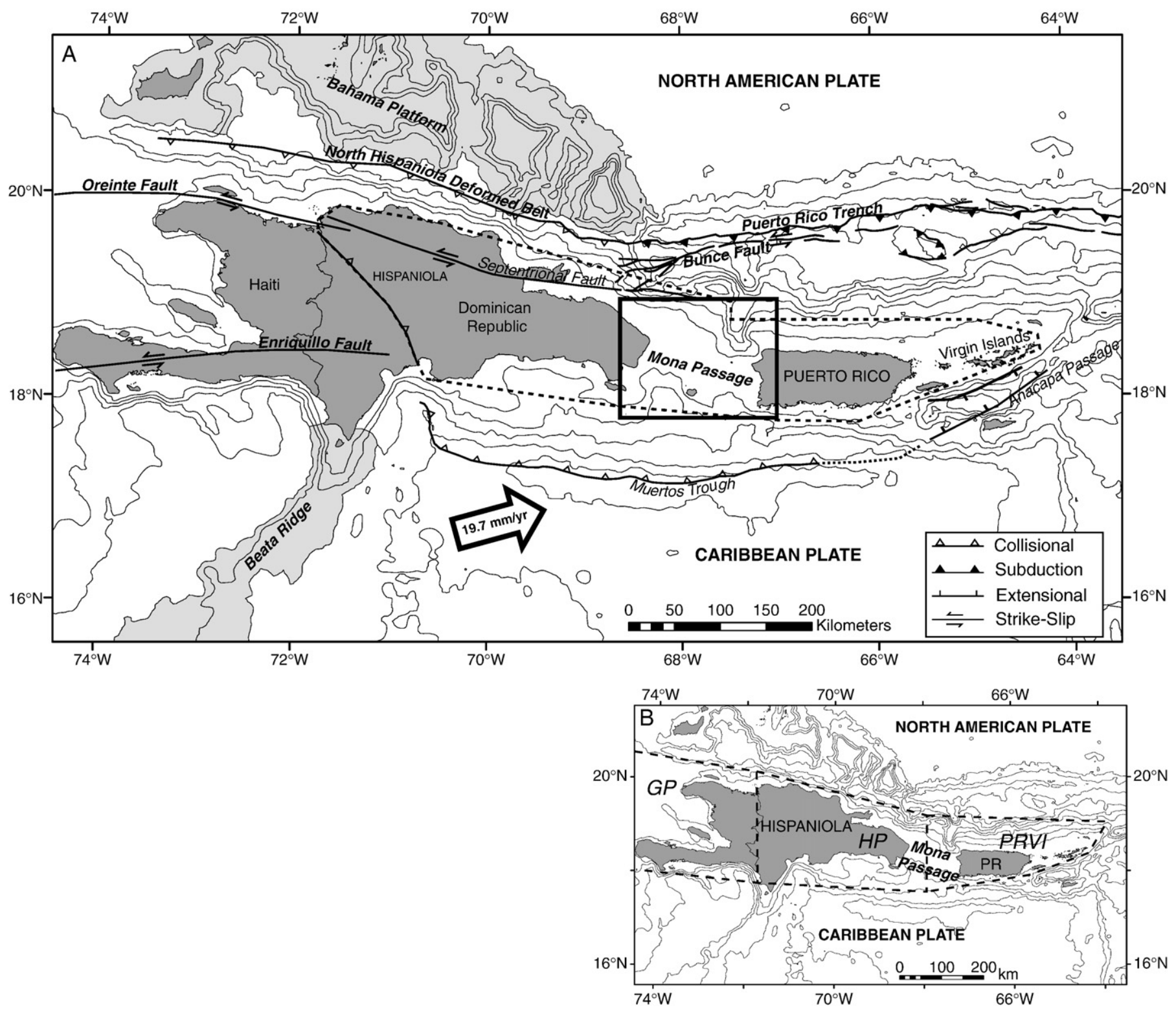

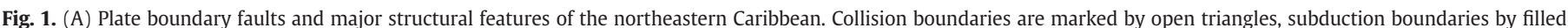

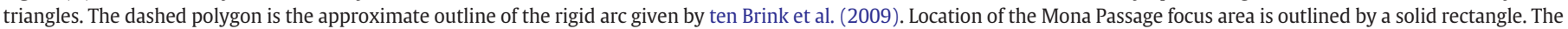

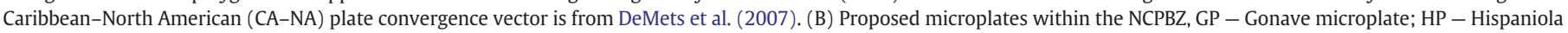
microplate; PRVI - Puerto Rico-Virgin Islands microplate.

2005), and normal faulting along the crest of a Puerto Rico-Virgin Islands compressional arch (e.g., Mann et al., 2005b).

In this paper we use newly-collected high-resolution multibeam bathymetry, new multi-channel seismic reflection profiles, and other existing geophysical datasets to discuss the style and cause of the intraarc extension within this arc setting which is currently undergoing compression along its northern and southern boundaries (Fig. 1). We further discuss the implications of this intra-arc extension to seismic and tsunami hazards for Puerto Rico and the Dominican Republic.

\section{Tectonic and geologic setting}

\subsection{Tectonic setting}

Eastern Hispaniola, Mona Passage, the island of Puerto Rico, and the Virgin Islands form the eastern end of the Great Antilles (Fig. 1A), the remnant of an intra-oceanic arc that formed along the boundary between the Caribbean (CA) and North American (NA) plates in the Cretaceous- early Paleogene period (Donnelly, 1989). Between the late Paleocene to early Oligocene, CA-NA relative plate motion changed from a N-S direction to a more easterly direction as a result of the collision of the arc with the Bahama carbonate platform (Pindell and Barrett, 1990). The current CA plate motion relative to NA is $19.7 \mathrm{~mm} / \mathrm{yr} \pm 0.4 \mathrm{~mm} / \mathrm{yr}$ towards $075.6^{\circ} \pm 0.9^{\circ}$ (DeMets et al., 2007). The boundary between the CA and NA plates, collectively known as the Northern Caribbean plate boundary zone (NCPBZ), is dominated by left-lateral motion, collision, and oblique subduction of the NA plate beneath the CA plate.

Analysis of seismicity, geophysical data, regional geology, and most recently GPS data, have lead to the division of the NCPBZ into as many as three microplates or tectonic blocks, which from east to west are the: Puerto Rico-Virgin Island (PRVI; Masson and Scanlon, 1991; Jansma et al., 2000), Hispaniola (Byrne et al., 1985), and Gonave (Mann et al., 1995) microplates (Fig. 1B). Campaign and some continuous GPS observations show that, within error, the PRVI microplate is moving at a similar rate and in approximately the same direction as the Caribbean plate (Fig. 2; Jansma et al., 2000; 


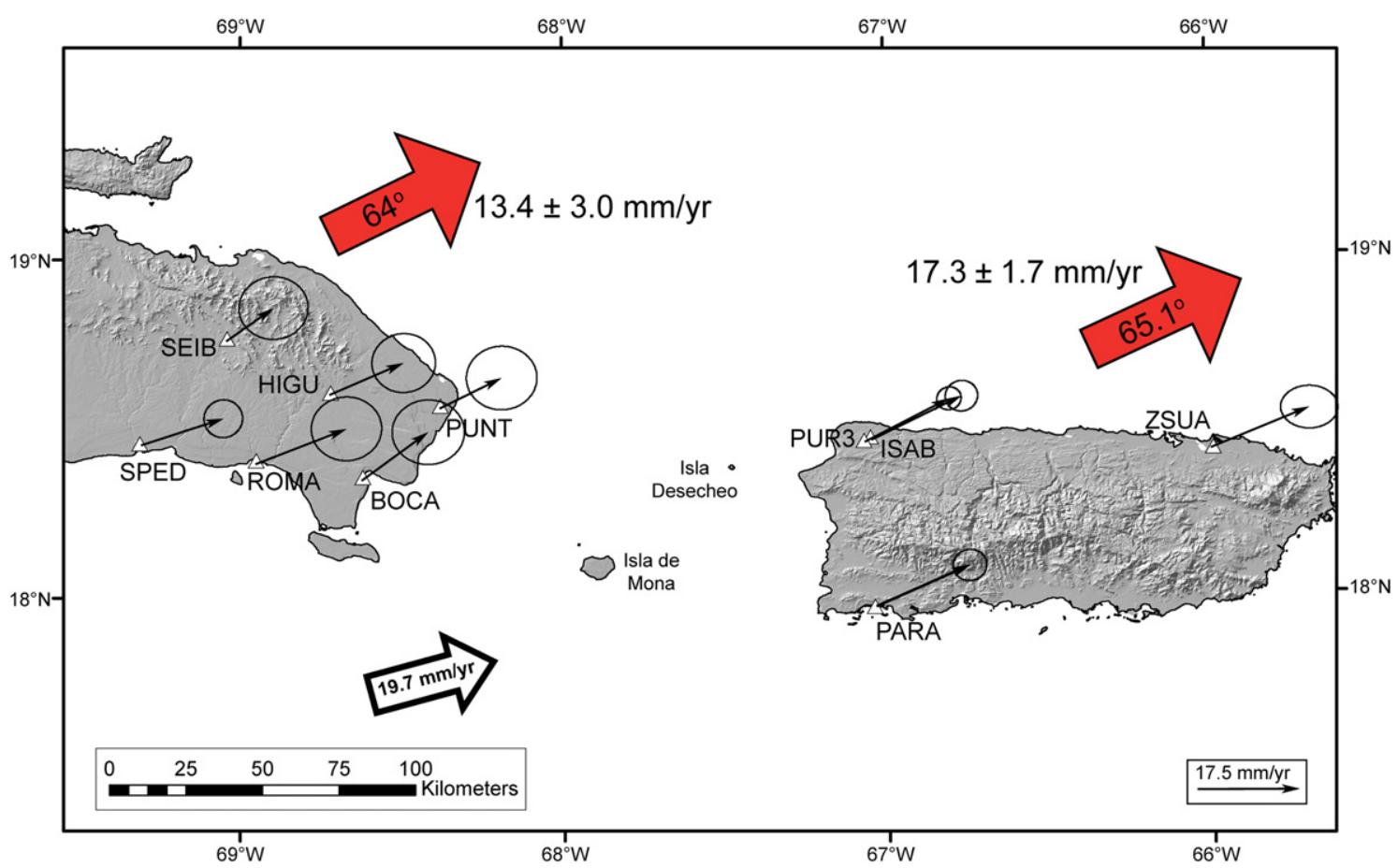

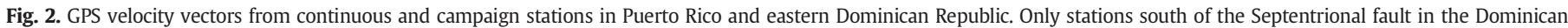

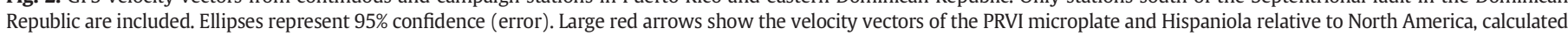
from the average velocities of the stations shown on each island. The CA-NA plate motion vector is from DeMets et al. (2007). Data from E. Calais, written comm. (2007).

Mann et al., 2002; Manaker et al., 2008). In Hispaniola, partitioning due to plate boundary structures and the collision with the Bahamas Platform (Fig. 1) is indicated by GPS velocities (Manaker et al., 2008). Several authors (e.g., Calais et al., 2002; Jansma et al., 2000; Mann et al., 2002) have suggested that the variation of GPS velocities between eastern Hispaniola and Puerto Rico reflects extension between the adjacent microplates in an ENE direction.

\subsection{Morphology and geology}

Mona Passage is an almost entirely submerged part of the Greater Antilles arc with water depths generally between 100 and $700 \mathrm{~m}$ (Fig. 3). The morphology of the seafloor in Mona Passage is composed of a mix of erosional, karst, depositional, and structural features, overprinted on the original layered fabric of the carbonate platform which is exposed almost everywhere across the passage. Karst morphology has been observed during submersible dives within the passage (Gardner et al., 1980; B. Heezen, unpublished observations; B. Greeson, pers. comm. 2008), suggesting that portions of the passage floor may previously have been at or above sea level. Numerous areas of the passage are shallower than $150 \mathrm{~m}$ and were therefore likely subaerially exposed during the Last Glacial Maximum sealevel lowstand.

Several significant features dominate the seafloor physiography of Mona Passage. At the north edge of the passage is Mona Canyon, a deep (about $5000 \mathrm{~m}$ at the deepest point) approximately $\mathrm{N}-\mathrm{S}$ trending, steep-walled canyon, which, based on the interpretation of seismic reflection data, is thought to be an extensional rift (Dolan et al., 1998; van Gestel et al., 1998; and others). The submerged E-W trending Desecheo Ridge connects Isla Desecheo (Fig. 3A), an outcrop of the Cretaceous-lower Oligocene arc volcanic basement, to Punta Higuero and borders the north side of the Mayagüez basin. South of the Mayagüez basin are the shallow reef-topped Bajo de Cinco and the insular reef platform extending off the southwest corner of Puerto Rico (Fig. 3A). Located centrally in the passage are the flat-topped Isla de Mona and the smaller Isla Monito, emergent outcroppings of the carbonate platform. Frank et al. (1998) proposed that Isla de Mona was uplifted by tectonic processes, which was not confirmed by our multibeam bathymetry (Fig. 3). To the southwest of Isla de Mona is Yuma basin, a partially sediment filled bathymetric low which has been interpreted by van Gestel et al. $(1998,1999)$ to be a rift basin, an interpretation which also was not confirmed by multibeam and seismic data (Granja Bruna et al., 2009).

With limited exposure of pre-Oligocene units, the composition and spatial distribution of the rocks below the Oligocene to Miocene carbonate platform succession across Mona Passage are poorly understood. Pre-Oligocene rocks are known to crop out along the crest and south wall of Desecheo Ridge (Nagle et al., 1978) and form the bulk of Isla Desecheo (Seiders et al., 1972). Seiders et al. (1972) assigned the rocks on Desecheo, which are chiefly deformed dacitic volcanoclastics rocks (volcanic sandstones, mudstones, and conglomerates) with secondary interbedded calcareous foraminiferal mudstones and sandstone, to the Eocene Río Culebrinas Formation. The Río Culebrinas Formation is a unit of the Eocene Cerrillos Belt (Dolan et al., 1991), a sequence of turbidite facies that crops out along the northwest coast of Puerto Rico along the Rincon Peninsula. It is unclear if the remainder of Mona Passage is underlain by units of the Cerrillos Belt or if the carbonate platform lies directly over the Cretaceous to Early Eocene island arc basement or metavolcanics seen cropping out along the east wall of the Mona Canyon (Heezen et al., 1985). Given this uncertainty, all rocks below the units of the carbonate platform are considered in this paper to be basement.

The late Oligocene to Pliocene PRVI carbonate platform which extends from the eastern Dominican Republic to the Virgin Islands (van Gestel et al., 1998) is a thick sequence (1706 m thick in the 4 CPR test well located on the coast approximately $10 \mathrm{~km} \mathrm{NE}$ of Arecibo; Briggs, 1961) of shallow marine carbonate and siliciclastic units. While the carbonate platform stratigraphy (San Sebastian Formation through Quebradillas Limestone) has been extensively studied adjacent to Puerto Rico (Monroe, 1980; Moussa et al., 1987; Larue and Berrong, 1991; van Gestel et al., 1998), knowledge of the carbonate units in Mona Passage is predominantly derived from scattered dredge and 

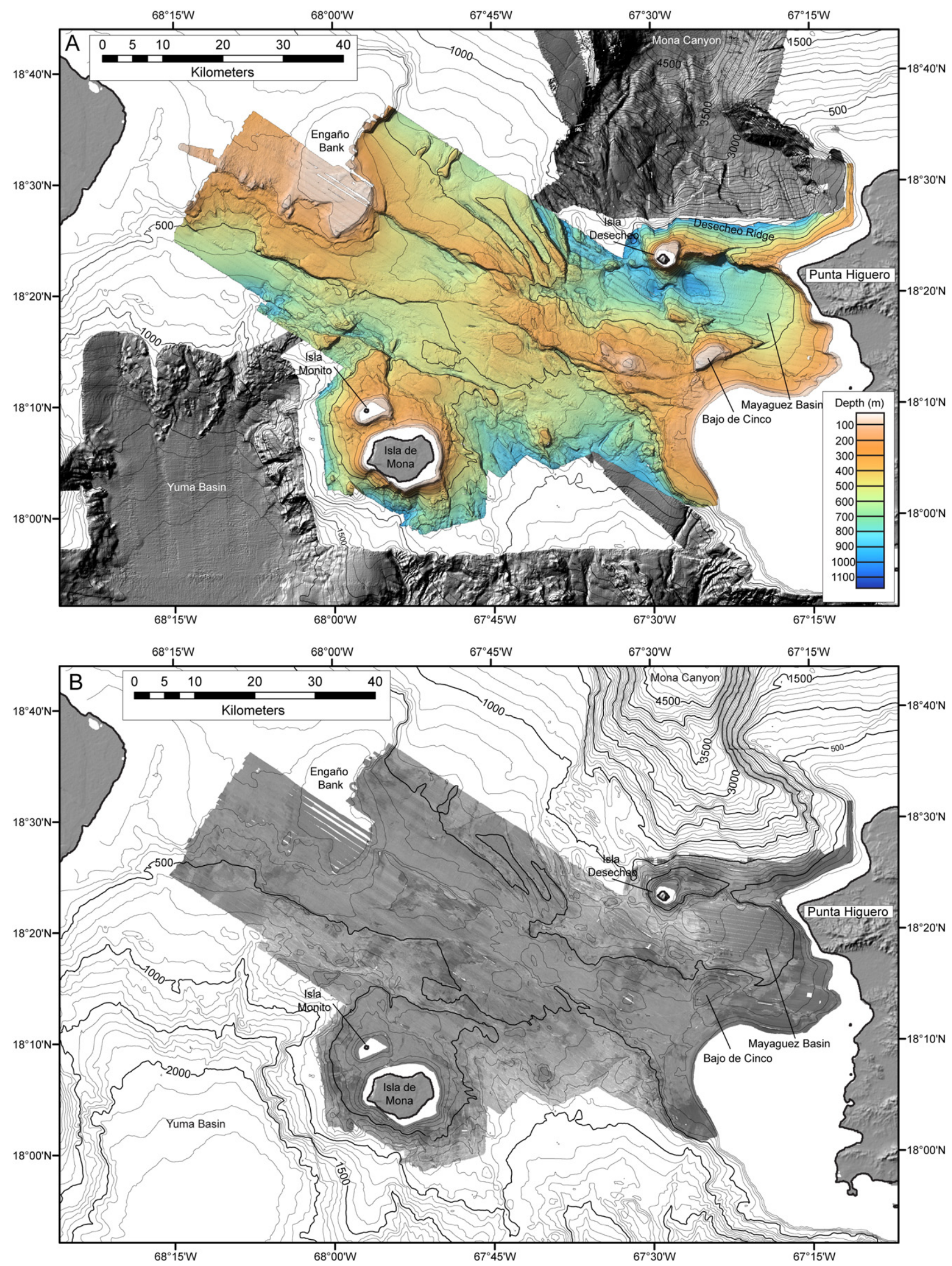

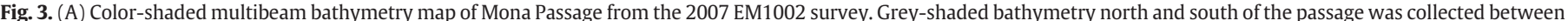

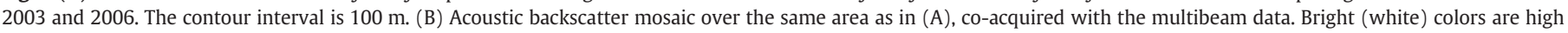
reflectivity, dark (grey-black) are low reflectivity. 
dive samples. Disruption of the carbonate platform by Mona Canyon and Desecheo Ridge has precluded definitive correlation of seismic horizons identified from northern Puerto Rico (Moussa et al., 1987; van Gestel et al., 1998) to Mona Passage. Correlation with the coastal stratigraphy of the eastern Dominican Republic is limited by a lack of detailed information in that area.

Using the North Coast basin of Puerto Rico (Briggs, 1961) as an analog, the base of the platform carbonate succession in Mona Passage is likely the siliciclastic San Sebastian Formation. The San Sebastian Formation unconformably overlies Cretaceous arc and Eocene basin formations, reflecting the shift from Eocene deformation to a long period of tectonic stability. Overlying the San Sebastian Formation is a conformable sequence of late Oligocene to late Miocene or early Pliocene limestones. Late Miocene to Pliocene age dolomite (Isla de Mona dolomite) and limestone (Lirio limestone) are exposed on Isla de Mona (Kaye, 1959; Briggs and Seiders, 1972; Gonzalez et al., 1997). These limestones and dolomites do not correlate compositionally with the units of northern and southern Puerto Rico and are likely the result of localized reef build up (Ruiz, 1993). Although the thickness of the carbonate sequence exceeds $1000 \mathrm{~m}$ in some locations, estimates of true carbonate platform thickness across the passage cannot be made because of erosion and movement of fault blocks.

The platform carbonates are capped in places by post Miocene reef sequences and variable thicknesses of Quaternary sediments. Modern reefs are found along the crests of most shallow banks and the insular shelves of Puerto Rico and the Dominican Republic and are identifiable on the bathymetry and in the seismic reflection profiles. Quaternary sediments are predominantly restricted to basins adjacent to western Puerto Rico, the largest of which is the Mayagüez basin.

\section{Data sets and methods}

In March 2007, the U.S. Geological Survey (USGS) collected approximately $4200 \mathrm{~km}^{2}$ of differential GPS navigated high-resolution multibeam swath bathymetry (Fig. 3A) and co-acquired acoustic backscatter (Fig. 3B) in Mona Passage using the hull-mounted Kongsberg EM1002 sonar system installed on the NOAA Ship Nancy Foster. Almost complete seafloor coverage of Mona Passage was obtained between 100 and $900 \mathrm{~m}$ water depth. The final edited data are gridded at a pixel resolution of $30 \mathrm{~m}$. Complementing this survey are bathymetry data collected by the USGS in April-May 2006 to the north and south of the Nancy Foster survey area using the SeaBeam 2112 multibeam system installed on the NOAA Ship Ronald H. Brown $(50 \mathrm{~m}$ pixel resolution; Fig. 3A). LIDAR data and shallow water multibeam adjacent to the west coast of Puerto Rico acquired by the NOAA Center for Coastal Monitoring and Assessment, and hydrographic soundings collected by the National Ocean Service (http://www.ngdc.noaa.gov/ $\mathrm{mgg} /$ bathymetry/hydro.html) were used to provide coverage in some shallow water areas.

Approximately $450 \mathrm{~km}$ of multi-channel seismic (MCS) reflection profiles were collected across Mona Passage as part of a larger survey by the USGS around Puerto Rico and the U.S. Virgin Islands in October 2006 aboard the $R / V$ Pelican (Fig. 4). These data were acquired using a $105 \mathrm{in}^{3}$ GI gun (except for line 55 and 56 in which a $35 \mathrm{in}^{3}$ GI gun was used) and a $240 \mathrm{~m}$ long, 24-channel receiving array coupled to a Geometrics StrataView acquisition system. Ship speed during acquisition was approximately $4.5 \mathrm{kts}$ and shot spacing was approximately $85 \mathrm{~m}$ (42 s) for the $105 \mathrm{in}^{3}$ GI gun and approximately 30-40 m (15-18 s) for the 35 in $^{3}$ GI gun, with Differential GPS used for navigation. Seismic

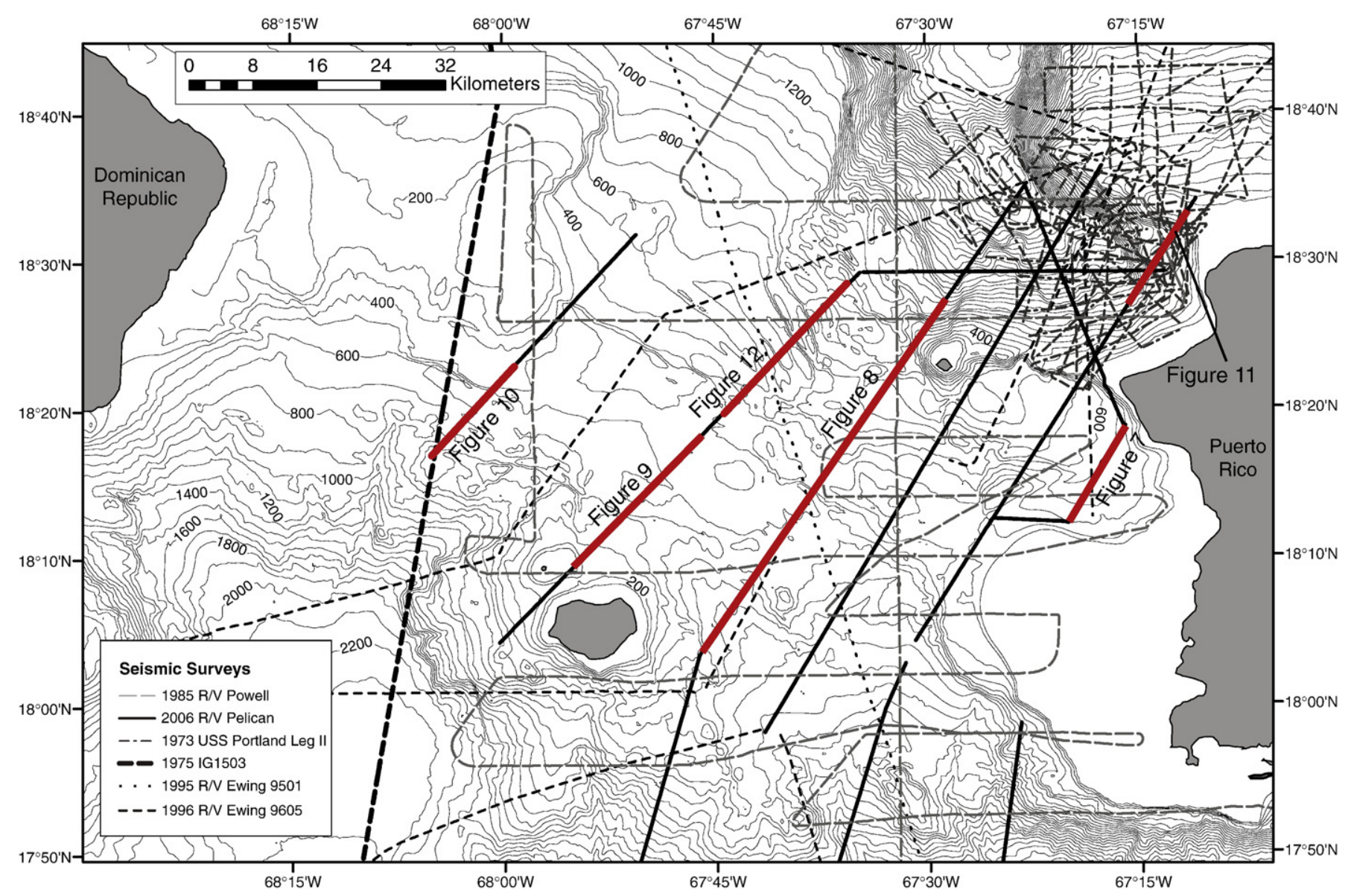

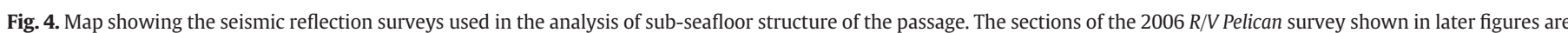
marked in red. Contour interval is $100 \mathrm{~m}$. 
processing included normal moveout correction, bandpass filtering (Ormsby zero phase bandpass), common depth point (CDP) stacking, and Stolts F-K post-stack migration. Additional seismic lines from $R / V$ Ewing cruises EW9501 and EW 9605, R/V Ida Green cruise IG1501, 1973 USS Portland cruise (Gardner et al., 1980; Heezen, unpublished data), and single-channel airgun profiles from the $1985 \mathrm{P}-3-85 \mathrm{R} / \mathrm{V}$ Powell cruise (Edgar and Scanlon, 1987) are used to complement the new seismic reflection data (Fig. 4).

\section{Results}

\subsection{Morphology}

The presence of erosional and depositional features is both beneficial and detrimental to the interpretation of the seafloor expression of structures within Mona Passage (Fig. 5A). Erosion serves at times to enhance the subtle surface and subsurface expression of faults and fractures, but may also create features that can appear at first glance to be tectonic in origin. In general, scarps created by erosion tend to be less linear than fault scarps and are more rounded (convex) in profile. However, there are exceptions to this generalization, such as the linear erosional scarp immediately NW of Isla Monito (Fig. 5B). In addition, bottom currents have eroded the seafloor along bedding planes of the carbonate formations, in some cases creating a "stairstep" morphology that resembles densely-spaced faults.

Several sections of the seafloor within Mona Passage have morphologies suggestive of bottom current erosion and deposition mechanisms (Fig. 5B and C). Extensive erosion, in the form of current scour and carbonate dissolution of sections of the carbonate platform units within the passage, are seen in several places, notably Engaño Bank, to the west of Bajo de Cinco, and to the northwest of Isla Monito (Figs. 3A and 5). This style of erosion is most clearly seen on Engaño
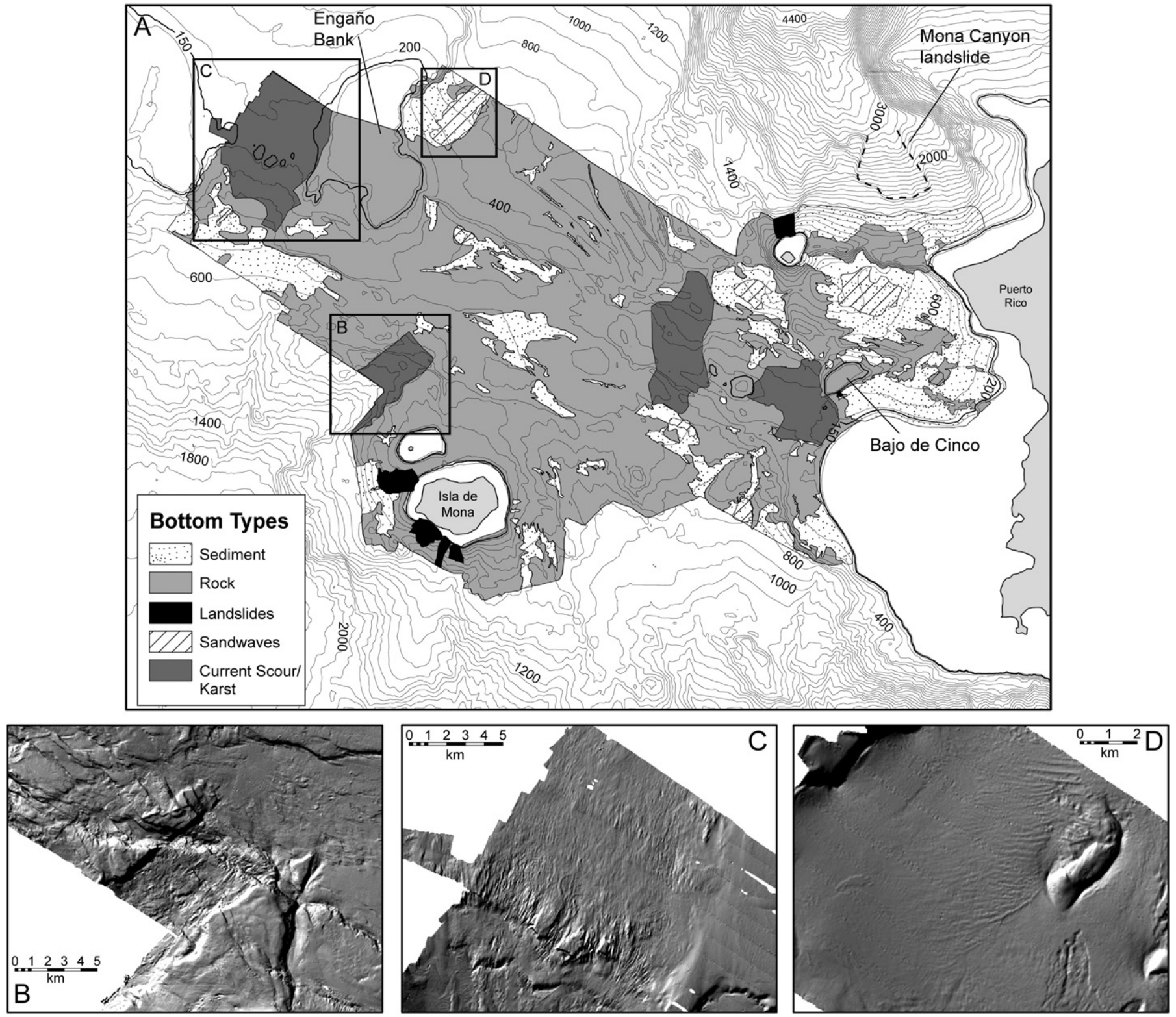

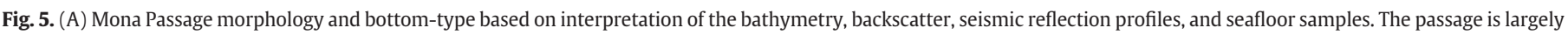

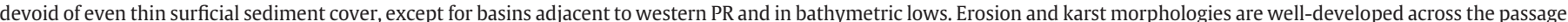

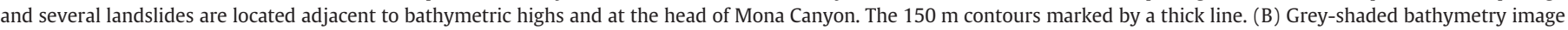

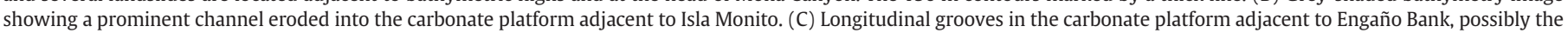
result of tidal current scour or from karst development (karren). (D) Sandwaves, likely tidally induced, in thin sediment cover at the northwest corner of the passage. 
Bank, where closely-spaced, elongated grooves have been cut into the flanks and top of the south-side of the bank (Fig. 5C), similar to longitudinal grooves created by rapid, high-volume water flow (e.g., Baker, 1978) or karren (clint and grike karst) landforms (Ford and Williams, 2007). Smoothing of the seafloor is also noted in a number of locations and in most cases exposes subtle structural features masked in adjacent areas that have rougher surface textures. Except in the deeper structural basins (e.g., Mayagüez basin), the backscatter data (Fig. 3B) indicates only minor sediment accumulation, predominately in lows adjacent to fault scarps and within depressions created by seafloor erosion (Fig. 5A and D).

\subsection{Structural framework}

Faults are interpreted based on bathymetric expression and offset of horizons on seismic reflection profiles (marked as certain or likely on Fig. 6). Faults are marked as "possible" on Fig. 6 where seafloor lineaments are either not crossed by seismic reflection profiles, or horizons are poorly resolved in the seismic data, or where seafloor erosion is extensive.

Faults within the passage dominantly strike between $\mathrm{W}\left(270^{\circ}\right)$ to NNW $\left(340^{\circ}\right.$ ), with distribution centered at $305^{\circ}$ (Fig. 6). Several faults along the eastern edge of the passage are likely extensions of faults identified on Puerto Rico (see below), but a connection between faults in the Dominican Republic and western Mona Passage could not be identified because of limited high-resolution bathymetry coverage along the Dominican coast. Offset piercing points were not observed along any of the major faults within the passage, suggesting that faults are predominantly normal. Almost all the faults identified in the seismic data, cut the entire thickness of the late Oligocene-Pliocene carbonate platform sequence. However; limited stratigraphic control precludes accurate determination of the displacement and throw on most faults, except where the basement horizon is identified. A lack of even a thin surficial sediment accumulation across most of the passage floor precludes identification of active faults (see below for exceptions).

Three regions with distinct fault orientations and interactions, the Mayagüez Basin, Central and Western Passage, and Mona Canyon regions, are discussed next.

\subsubsection{Mayagüez basin region}

The Mayagüez basin region encompasses the region between Desecheo Ridge to just south of Bajo de Cinco, and from the west coast of Puerto Rico to immediately west of Isla Desecheo (Fig. 3A). The Mayagüez basin appears to be an extensional basin (half-graben) filled with thick deposits of Pliocene (?) to Recent sediments (Fig. 7). The ages are tentative and are based on the assumption that horizons above and parallel to the acoustic basement horizon are carbonate platform units, and horizons that onlap these basement-parallel units are Pliocene or younger basin-fill sediments (Fig. 8).

The Mayagüez basin is characterized structurally by N-dipping tilted blocks associated with S-dipping normal faults striking $\mathrm{W}$ to WNW $\left(270-300^{\circ}\right)$ that have large throws. The most prominent of these is the Desecheo Ridge fault, which strikes approximately $\mathrm{W}$

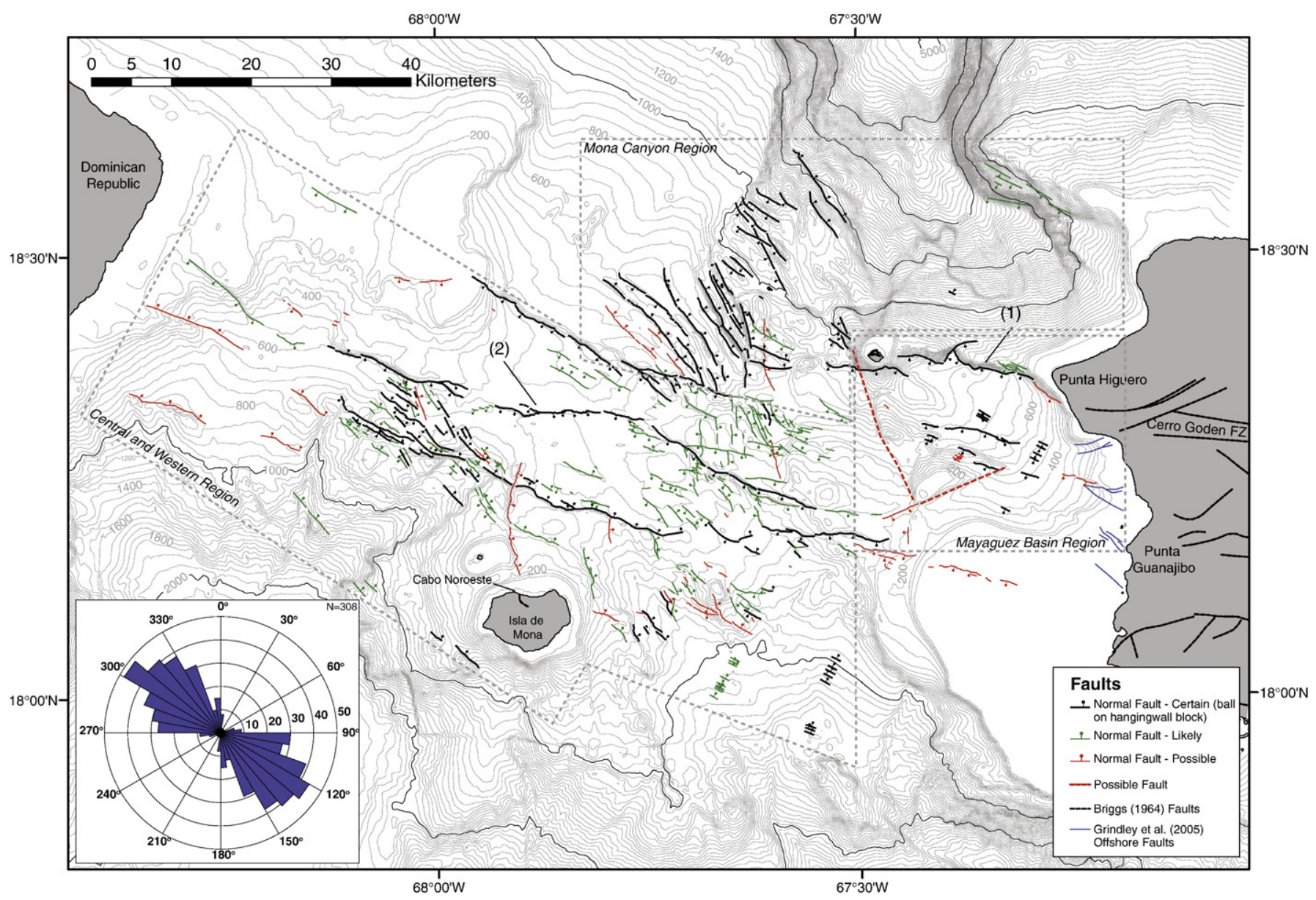

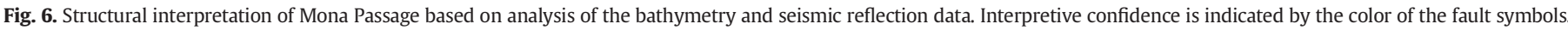

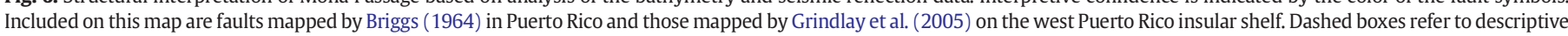
sections in the text. Inset: rose plot showing the strike direction of faults within the passage longer than $1000 \mathrm{~m}$, from which the dominant WNW to NW-strike can be seen 

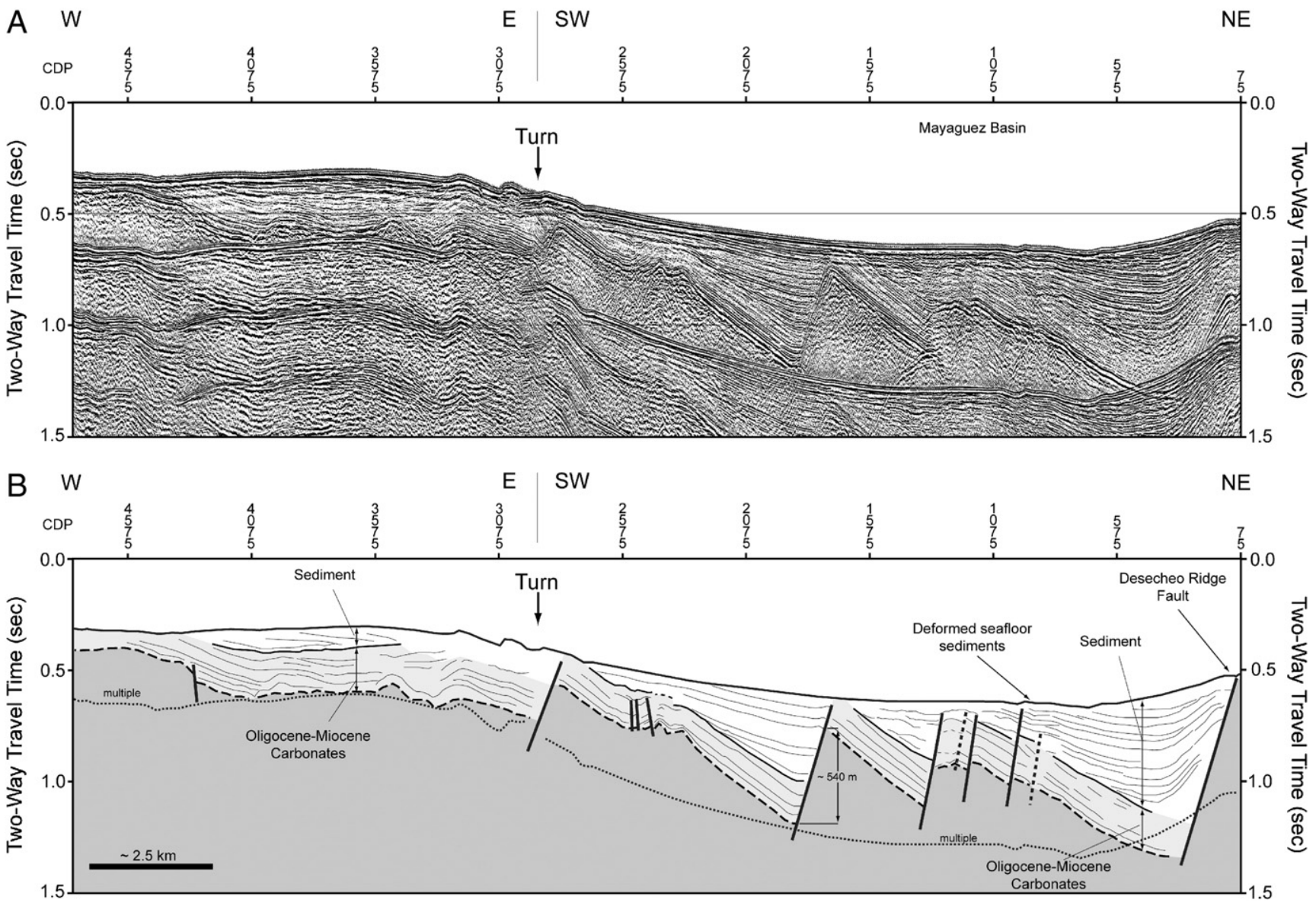

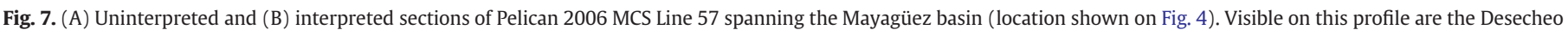

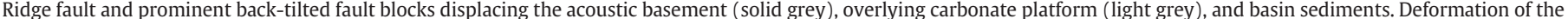
seafloor is observed above one of the normal faults in the basin. Possible faults are dashed. Vertical Exaggeration (VE) is $\sim 6 \times$.

from the insular shelf off Punta Higuero to Isla Desecheo, where it steps to the south of the island and continues west, terminating against faults of the Mona Canyon area (Figs. 3A and 6). Based on the orientation of the Desecheo Ridge fault and its associated splays, it does not appear that the Desecheo Ridge fault is a direct extension of the main trace of the Cerro Goden/Great Southern Puerto Rico fault as previously proposed (Briggs, 1964; Hippolyte et al., 2005; Mann et al., 2005b). Rather, the Desecheo Ridge fault may be a stepover strand of the Cerro Goden fault, or the Cerro Goden fault is associated with faults buried beneath the sediments of the Mayagüez basin.

Normal faults south of the Desecheo Ridge fault within the Mayagüez basin and exposed on the north side of Bajo de Cinco displace the Miocene carbonate platform section as well as most, if not all, the overlying sediment (Figs. $3 \mathrm{~A}$ and 7). The displacement of surficial sediments within the Mayagüez basin (Figs. 7 and 8) suggests that these faults are currently active. The throw on one of these faults (Fig. 7), based on offset of acoustic basement on the timemigrated $R / V$ Pelican seismic lines and assuming an approximate average velocity of $2000 \mathrm{~m} / \mathrm{s}$ for overlying sediment and $2750 \mathrm{~m} / \mathrm{s}$ for carbonate platform units (van Gestel et al., 1998), is estimated to be approximately $540 \mathrm{~m}$. These faults appear to extend from the Puerto Rico insular shelf to south of Isla Desecheo where their bathymetric expression disappears and seismic reflection coverage is insufficient to determine if they are present in the subsurface. The eastern ends of some of these Mayagüez basin faults may connect with faults identified nearshore by Grindlay et al. (2005) between Punta Higuero and Punta Guanajibo (Fig. 6).

A N-striking bathymetric scarp extends from the insular shelf edge west of Bajo de Cinco to south of Isla Desecheo, with a similarly oriented scarp continuing north of Isla Desecheo downslope into Mona Canyon (Fig. 6). It is not clear if these scarps are a product of erosion or are faults. If these scarps are indeed fault-related, they may form a structural boundary between Mayagüez basin and the rest of Mona Passage. A linear scarp along the south-side of Bajo de Cinco may connect at its southwest end with a prominent W-striking crosspassage fault and is buried by sediments of the Mayagüez basin at its northeastern end. The NE trend of this feature is markedly different from the dominant NW-strike of faults in the passage. Seismic reflection profiles across these bathymetric features (e.g., Fig. 7) do not provide sufficient evidence to classify either of these features as faults.

\subsubsection{Central and western area}

The central and western Mona Passage (Figs. 3A and 6) contain faults of various lengths and orientations, resulting in a complex structural architecture whose interpretation is further complicated by extensive seafloor erosion in the area. As with other faults identified throughout the passage, there is no clear evidence on the bathymetry for lateral offset along faults in the central and western area, suggesting that these faults are normal. Dominating the central and western area are a number of long $(>40 \mathrm{~km})$ faults, with seafloor traces that strike generally toward the WNW (290 to $300^{\circ}$ ). These long faults are curved in places, and are composed of splays and disconnected and overlapping segments (Fig. 6) that are typical of normal faults (e.g., Gawthorpe and Hurst, 1993). These long normal faults cut the surficial sediment cover, where present, along their traces, except at their western ends south of Engaño Bank (Fig. 5A). One of these faults, about $13 \mathrm{~km}$ north of Isla de Mona, corresponds 

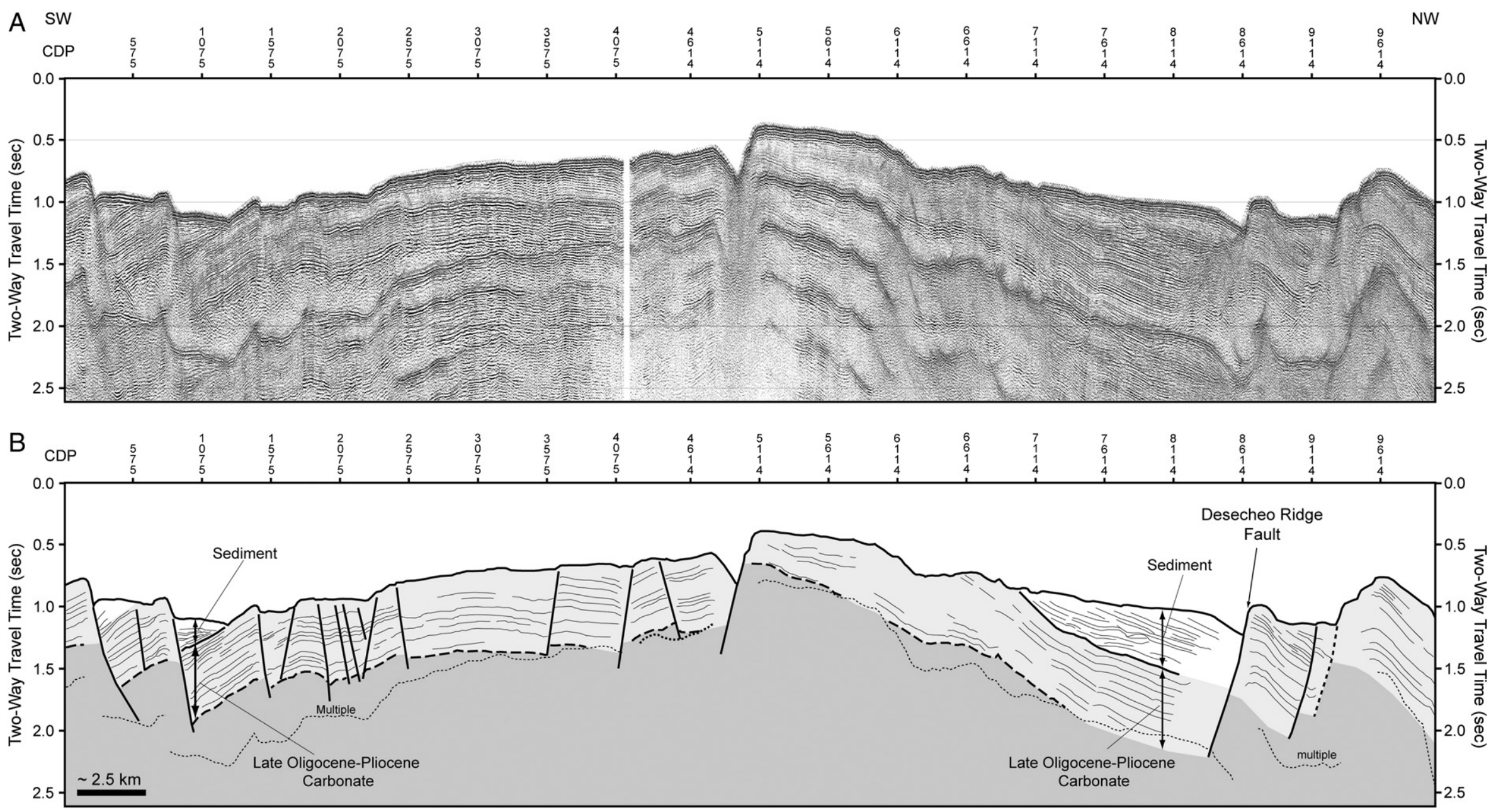

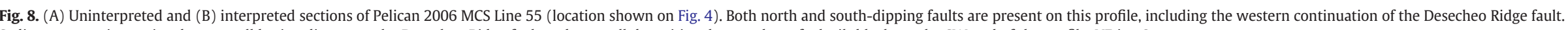
Sediment cover is restricted to a small basin adjacent to the Desecheo Ridge fault and to small depositional traps above fault tilt blocks at the SW end of the profile. VE is $\sim 6 \times$. 
with the Isla de Mona fault zone proposed by Rodriguez et al. (1977). In the subsurface, these long faults dip towards the NE and SW and display only limited block tilting unlike the tilted blocks in the Mayagüez basin (Figs. 9 and 10). The limited tilt may reflect oblique slip rather than pure dip-slip on the faults. The amount of vertical displacement on these faults cannot be assessed because of limited sediment cover and the presence of strong multiples, which obscure the acoustic basement.

Short, NW- to NNW-striking faults, some of which dip to the NE and others to the SW are observed northwest of Isla de Mona. These faults do not appear to cut the longer WNW-striking cross-passage faults discussed above. The western ends of these short NW- to NNWstriking faults are covered by sediment, suggesting that these faults may currently be inactive. In the subsurface these short faults extend into acoustic basement and often show small amounts of listric and antithetic fault development (Fig. 10). It is unclear to what degree these closely-spaced short NW-NNW-striking faults interact with each other and with the adjacent longer W- to WNW-striking faults at depth, because the roots of these faults are obscured by a strong multiple in the seismic record. NW- to NNW-striking faults are also present east of Isla de Mona but appear to be substantially longer than those to the NW of Isla de Mona. The total length of these faults east of Isla de Mona is unknown due to the lack of high-resolution bathymetry coverage over the region. A N-trending scarp is identified north of Isla de Mona (Fig. 6), which, if continued onto the island, would connect with a proposed fault that extends to the central part of the island (Briggs and Seiders, 1972).

Van Gestel et al. (1998) have proposed that extension of Mona Passage is accommodated by two rifts, Yuma on the SW side of the passage and Cabo Rojo on the SE. The Yuma basin appears as a significant depositional basin on the seismic reflection profiles without clearly defined bounding faults, and may be an isolated backarc-style basin, related to compression along the Muertos Trough (Granja Bruna et al., 2009). The site of the proposed Cabo Rojo rift does not appear to be a significant structural feature or depositional center.
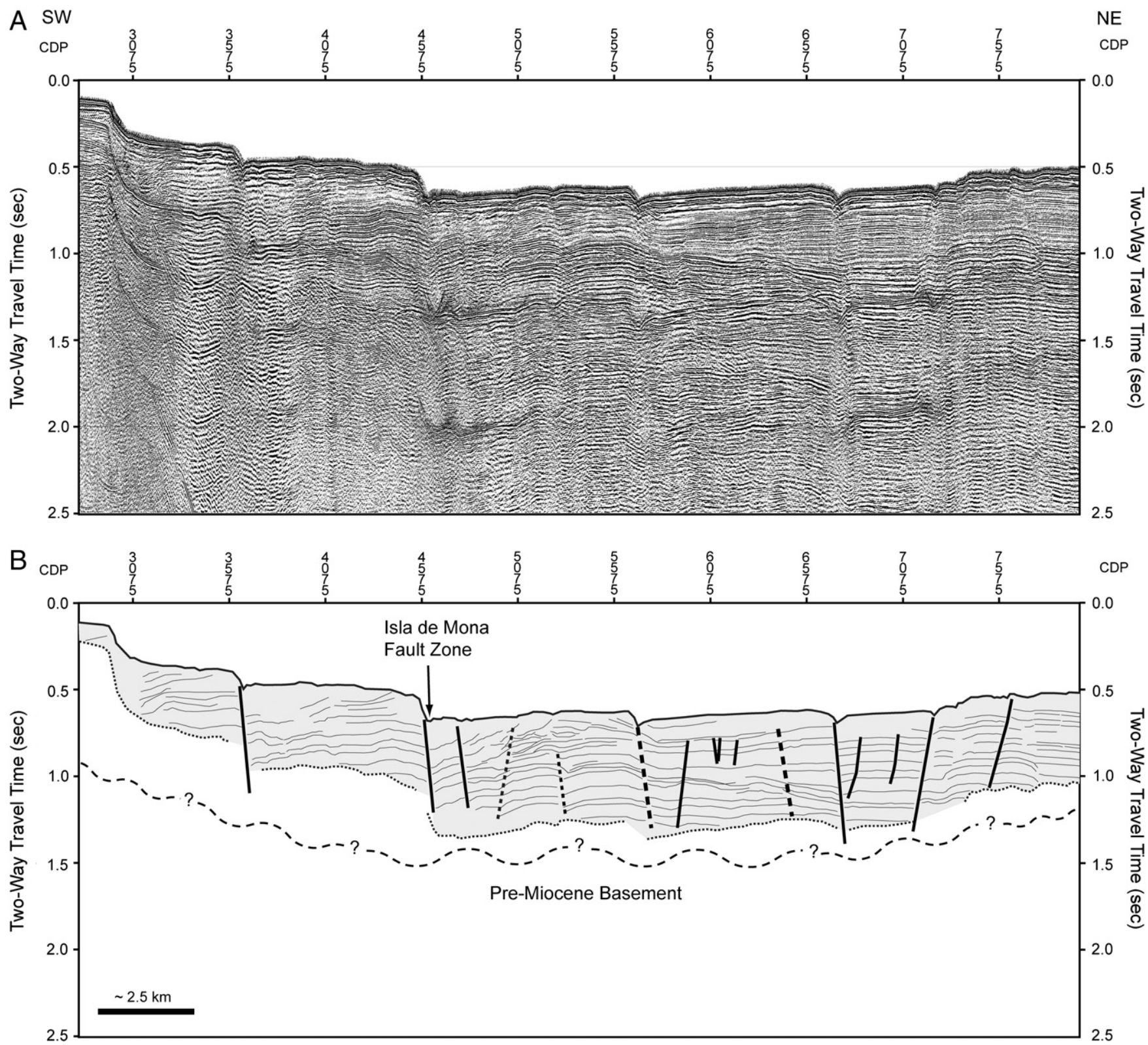

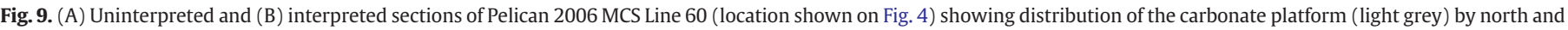

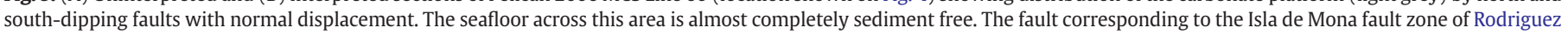
et al. (1977) is marked. Multiples obscure the contact between the carbonate platform and acoustic basement. VE is $\sim 6 \times$. 

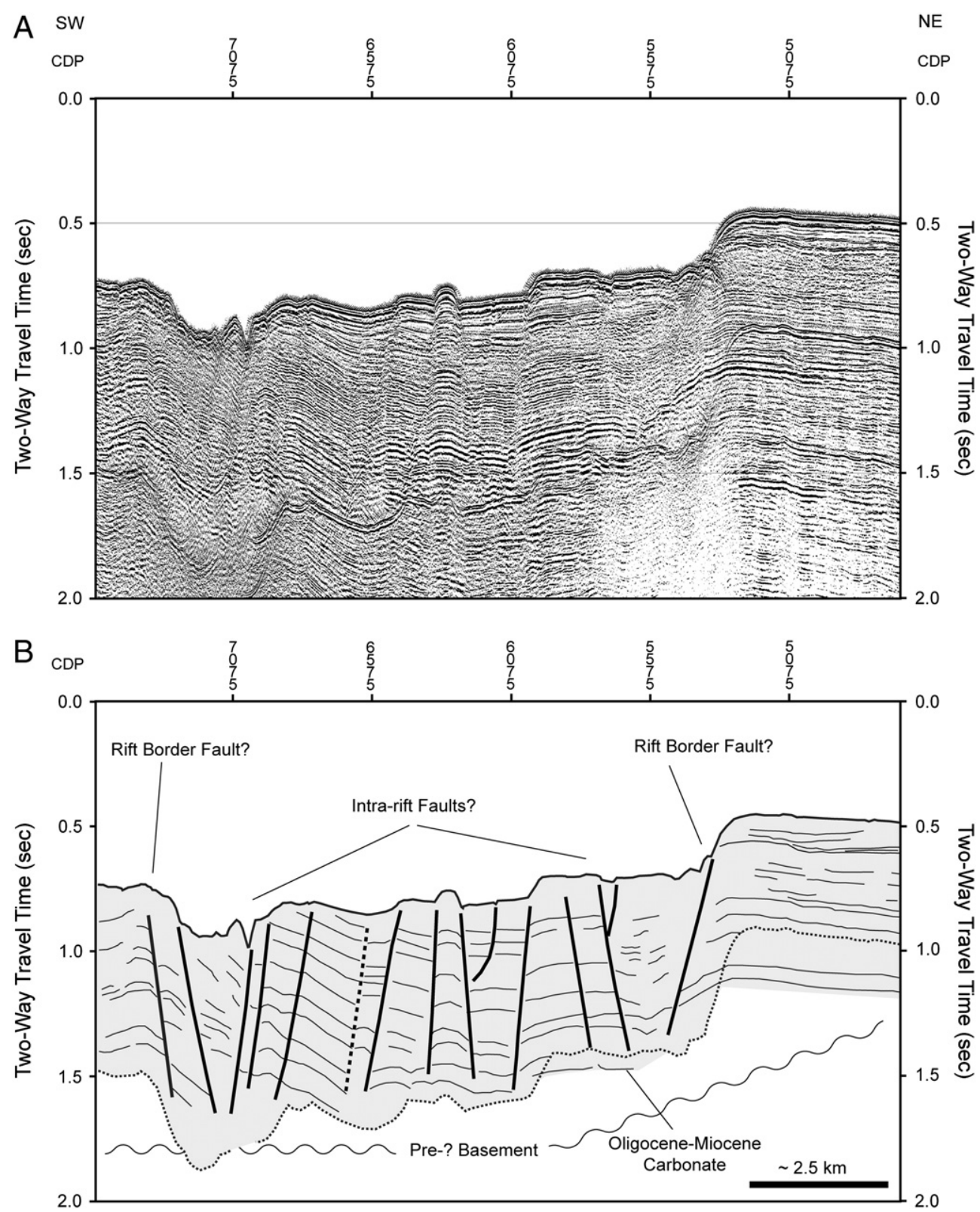

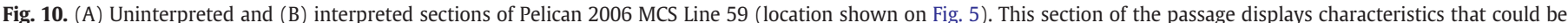

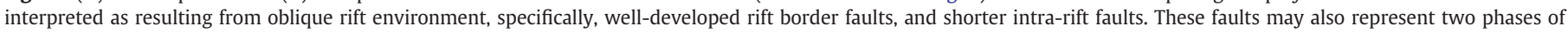
deformation. The carbonate platform/acoustic basement boundary is obscured in this profile. VE is $\sim 6 \times$.

\subsubsection{Mona Canyon region}

The Mona Canyon region is dominated by the approximately $20 \mathrm{~km}$ wide N-S oriented Mona Canyon that extends north from Desecheo Ridge (Figs. 3A and 6). At its southern end, the canyon abruptly changes its orientation to NW-SE. Incomplete bathymetry coverage prevents a full description of observed structures adjacent to those areas.

A significant body of evidence based on analysis of bathymetry (e.g., Gardner et al., 1980), seismic reflection profiles (e.g., Mercado and McCann, 1998), and seismicity (e.g., Ewing and Heezen, 1955) has been used to support the conclusion that Mona Canyon is an E-W opening rift whose steep walls are generated by normal fault scarps. Recent analysis of multi-channel seismic reflection data by Mondziel et al. (2006) suggests that the canyon is underlain by a half-graben, with a master normal fault forming the east wall of the canyon, and an antithetic normal fault along the west wall. Analysis of the new bathymetry and seismic reflection profiles across the N-S oriented section of the canyon finds no significant evidence that contradicts the half-graben interpretation, although a fault with a W- to NW- strike is visible on a seismic profile across the floor of the canyon north of the study area which is not predicted by the half-graben model.

NW-trending faults at the head of Mona Canyon, first identified by Gardner et al. (1980), are observed on seismic reflection profiles and as almost vertical walls on the bathymetry (Figs. 6 and 11). On the east side of the canyon head, the faults are down-thrown to the southwest, while those west of Isla Desecheo are predominantly down-thrown to the northeast. In the SW corner of Mona Canyon, NW-striking faults become more NNW-striking (between $300^{\circ}$ and $340^{\circ}$ ), and have more arcuate traces (Fig. 12).

Immediately west of Isla Desecheo, the NW-striking faults are intersected, but do not appear to be cut, by long W- to WNW-striking faults which may be a continuation of the western end of the Desecheo Ridge fault. Farther west, these NW-striking faults are cut by the trace of the northern-most long $\mathrm{W}$ - to WNW-striking fault of the central and western area, but no definitive offset of fault-trace piercing points across this long W- to WNW-striking fault are observed. 

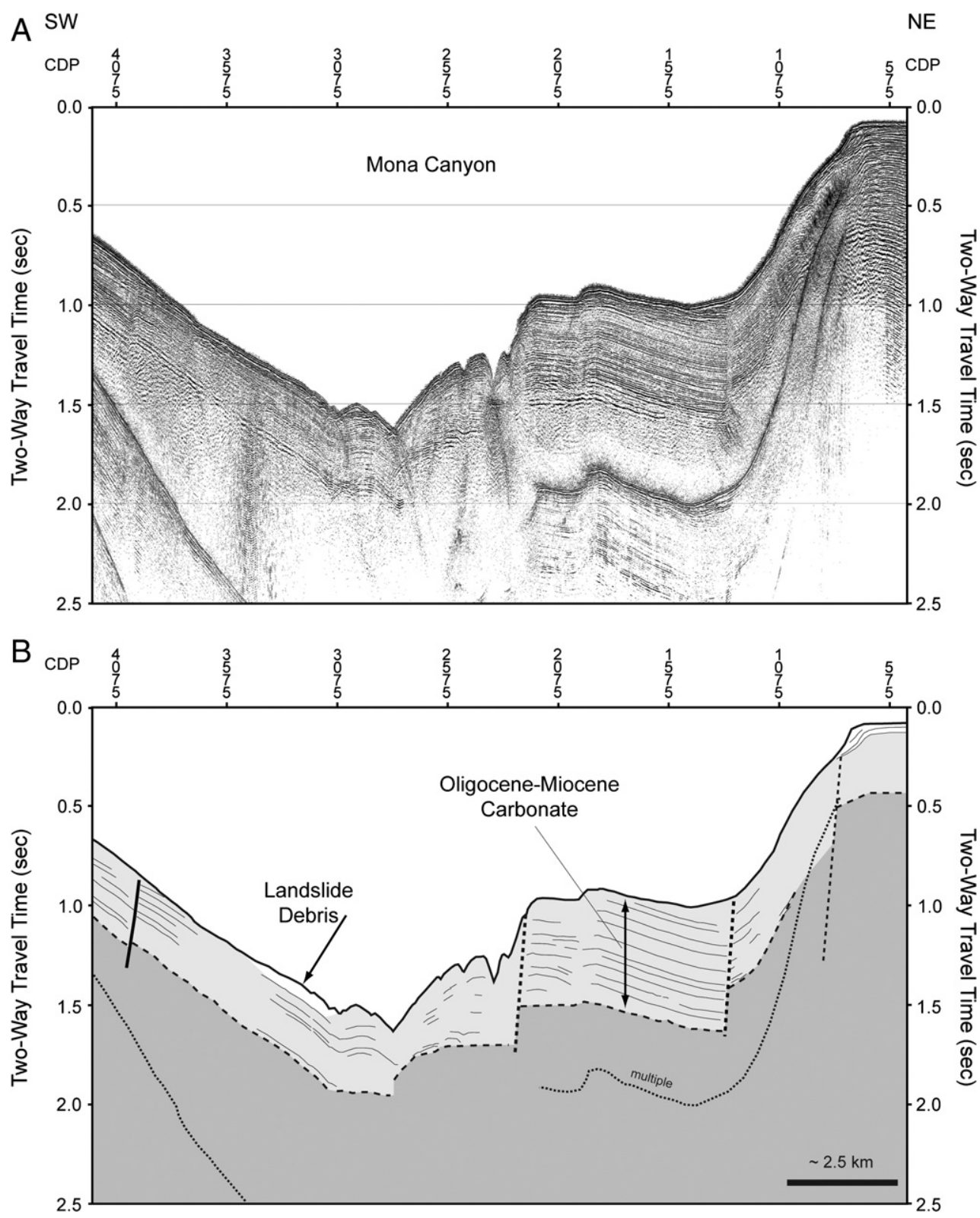

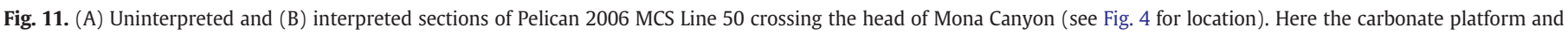

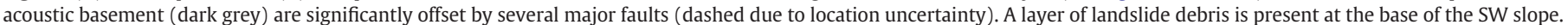
VE s $\sim 6 \times$.

\section{Discussion}

\subsection{Extensional deformation in Mona Passage - Style and amount}

From combined continuous and campaign GPS observations in western Puerto Rico and from the eastern Dominican Republic (E. Calais, unpublished data; Fig. 2) the average velocity of the PRVI block relative to NA (from four stations) is $17.3 \pm 1.7 \mathrm{~mm} / \mathrm{yr}$ in direction $65.1^{\circ}$, and the average velocity of eastern Hispaniola block relative to NA (from six stations) is $13.4 \pm 3.0 \mathrm{~mm} / \mathrm{yr}$ in direction $64^{\circ}$. In other words, the PRVI microplate may move $3.9 \pm 1.3 \mathrm{~mm} / \mathrm{yr}$ faster towards the ENE than the Hispaniola microplate.

Geologic estimates of the magnitude of stretching are commonly based on basin subsidence history and sediment backstripping, crustal thickness changes, and brittle fault or regional structural restoration and plate motion calculations (Allen and Allen, 1990; Kington and Goodliffe, 2008). Several factors make extension estimates across Mona Passage difficult. A lack of a well-developed passage-wide extensional basin and the diffuse nature of deformation within Mona Passage preclude robust extension estimates via subsidence histories. Furthermore, there is little to no information on current and preextension crustal thickness across the region. Finally, the pre-existing surface elevation of the passage is unknown, because it is unclear if the region underwent uplift along with Puerto Rico (ten Brink, 2005). The brittle fault method of estimating stretching is based on summing of fault heaves within a region. Although the brittle fault method typically underestimates the total extension because it overlooks smaller secondary faults not well imaged by seismic reflection profiles (Walsh et al., 1991), it provides a useful first-order estimate of stretching when other methods cannot be applied.

In the Mona Passage region, fault heaves are relatively small except in the Mayagüez basin (Figs. 7-9), suggesting that significant amounts of extension have not occurred throughout much of the passage. Using the heave of four faults with visible basement offset (Fig. 7) and the Desecheo Ridge fault, approximately $2.2 \mathrm{~km}$ of brittle extension is estimated to have occurred across the $13-\mathrm{km}$-wide 

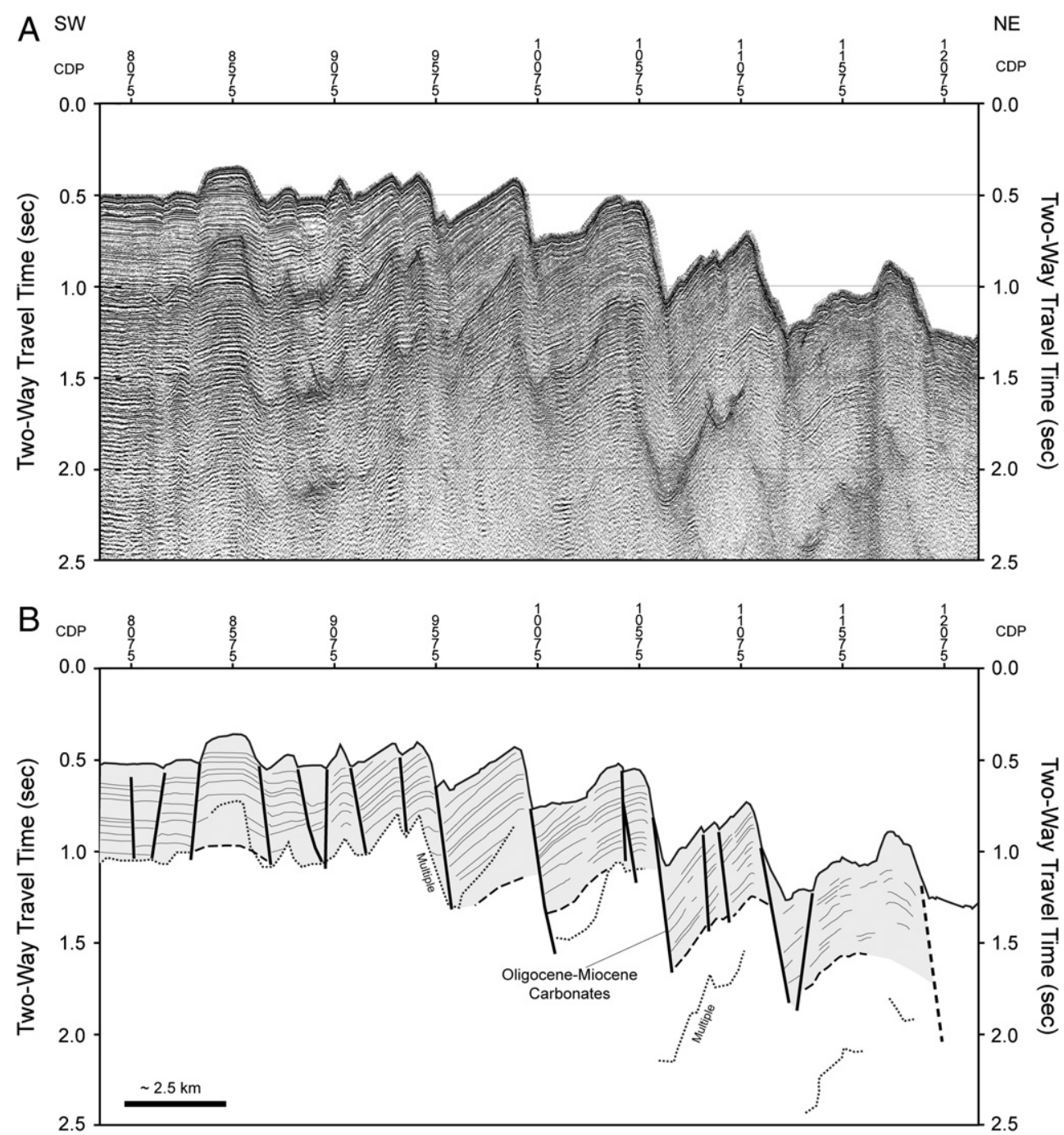

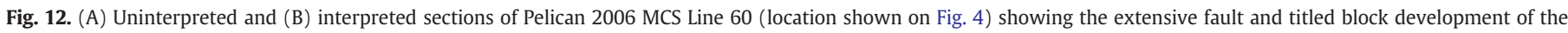

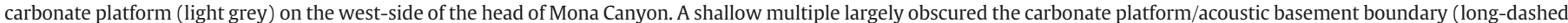
line). VE is $\sim 6 \times$.

Mayagüez basin, yielding a stretching factor of 1.2. Based on the extension rate from GPS velocities discussed above $(3.9 \mathrm{~mm} / \mathrm{yr})$ and assuming that motion of the blocks has been uniform since the termination of CCW rotation (Reid et al., 1991) and movement of the Bahamas platform pinning point to its present location (Mann et al., 2002) at approximately $4 \mathrm{Ma}$, as much as $15.5 \mathrm{~km}$ of extension could be expected to have occurred in the Mona Passage region. Extension of $15.5 \mathrm{~km}$ across the approximately $85 \mathrm{~km}$ width of the passage, measured from southwest of Isla de Mona across the head of Mona Canyon offshore of Aguadilla, yields a stretching factor of approximately 1.22 .

A different style of tectonic deformation is encountered in Mona Canyon at the northeastern part of the Mona Passage. There, deformation is focused on one or more N-striking normal faults, and on a NW-SE set of faults at the southern end of the deep and narrow canyon. How can the concurrent activity along the diffuse system WNW-oriented faults in Mona Passage and the almost orthogonal fault(s) of Mona Canyon be reconciled? One possibility is to appeal to rheological differences. Ten Brink et al. (2009) suggested that the Antilles arc is oceanic and is therefore quite rigid; hence, a small amount of extension will probably manifest itself in diffuse deformation across the arc. Mona Canyon on the other hand, may be located along the boundary of the rigid arc with the less-rigid forearc (Fig. 13). East of the canyon, Larue et al. (1998) and van Gestel et al. (1999) suggested the presence of a forearc basin while submarine dives on Mona block, NW of the canyon, have excavated rocks with arc affinity (Heezen et al., 1985). Upper-crustal brittle-plastic deformation in response to oblique extension may be focused along the strength gradient in the upper-crust. Although plausible, we could not find in the literature another example for this style of deformation. We propose to name this deformation style "rigid extender," because it may be the opposite of the commonly observed "rigid indenter," namely, a rigid block moves away from a less-rigid block instead of impinging upon it.

\subsection{Mona Passage deformation models}

\subsubsection{Oblique extension}

Multiple fault orientations may reflect oblique extension. The degree of obliquity is defined as the angle (clockwise) between the extension direction and the orientation of the border faults (Tron and Brun, 1991; McClay and White, 1995). Oblique rifts are often composed of rift border faults with a dominant component of normal dip-slip whose orientations are oblique to the direction of extension and intra-rift normal faults, which form at an angle to the border faults. Analog models and field examples (Morley et al., 1992; McAllister et al., 1995; McClay and White, 1995; Faerseth et al., 1997; McClay et al., 2002) show that intra-rift faults are oriented 


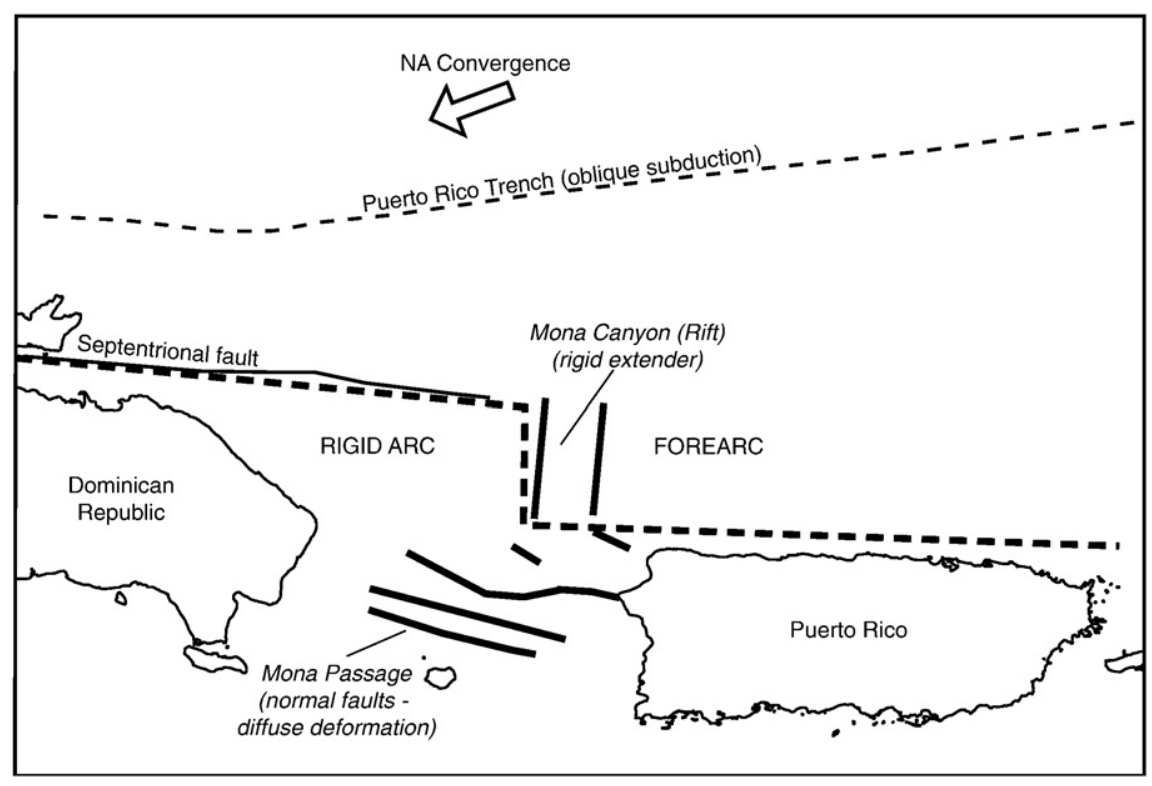

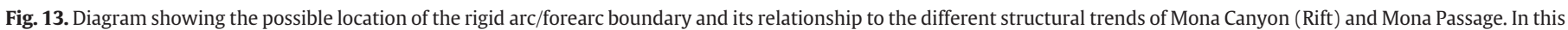
model, the N-S orientation of Mona Canyon is controlled by an $\mathrm{N}-\mathrm{S}$ oriented jog in the arc.

perpendicular to sub-perpendicular to the regional extension direction. This fault architecture can accommodate oblique extension without a need for strike-slip movement (Withjack and Jamison, 1986; Tron and Brun, 1991; McClay and White, 1995). Note, however, that pre-existing faults, changes in the direction of extension over time, and the degree of obliquity may also be important controlling factors in determining the orientation of faulting in many oblique rift settings (Bonini et al., 1997).

Several sections of Mona Passage display fault patterns that resemble those of oblique rifts (Figs. 6, 10, and 14). Intra-rift faults are represented by short NW-striking normal faults that are generally bordered to the north and south by long W- to WNW-striking normal faults that may play the part of the rift border faults. The average strike of the short NW-striking faults (intra-rift faults) is $325^{\circ}$. The perpendicular direction to these intra-rift faults is $55^{\circ}$, and is interpreted on the basis of analog models and field examples to be the approximate extension direction. This $55^{\circ}$ azimuth is close to the opening direction of $65^{\circ}$ suggested by GPS measurements. The angle between the $55^{\circ}$ extension direction and the average $295^{\circ}$ strike of the long W- to WNW-striking faults (border faults) is $60^{\circ}$ (Fig. 14B); therefore oblique extension in Mona Passage can be defined as moderate (McClay and White, 1995).

An oblique extension model also satisfies the observation of contemporaneous movement on multiple fault sets of different orientations. That said, oblique rift morphology across Mona Passage does not appear to be as well-developed as it is in areas such as the Ethiopian rift (Morley et al., 1992), which may be a reflection of the young age of rifting.

\subsubsection{Evaluation of previous deformation models}

Several models have previously been proposed to explain the diffuse pattern of deformation in Mona Passage. Three of the most often used models to explain extension in the passage, single-phase extension, poly-phase extension, and extension during rotation, are evaluated against the new geophysical dataset presented here.

5.2.2.1. Poly-phase extension. Multiple fault trends in Mona Passage may represent several phases of deformation of the NCPBZ resulting from a change in deformation style or from variations in a continuously operating mechanism (Fig. 15A). For example, Hippolyte et al. (2005) distinguished several phases of extension recorded in the Miocene carbonate units onshore Puerto Rico, with N-S extension on W-striking normal faults, followed by E-W extension in Mona Passage on $\mathrm{N}$ - to NW-striking normal faults, that are themselves reactivated pre-Oligocene basement faults. Apparently, this shift in extension direction resulted from the termination of rotation in the early Pliocene and a change to enhanced E-W opening between Hispaniola and Puerto Rico. NW-striking basement faults, only some of which cut Miocene formations, are also found in the Cordillera Oriental of the eastern Dominican Republic (García Senz et al., 1997). A poly-phase diffuse deformation model could be a tectonically reasonable explanation for the pattern of deformation in the Mona Passage; however, as far as can be determined, their cross-cutting relationships do not indicate different phases of activity. Earthquake focal mechanism solutions do not clearly define a preferred rupture orientation.

5.2.2.2. Single-phase extension. A number of proposed models (e.g., Vogt et al., 1976; Speed and Larue, 1991) have suggested that Mona Passage, and the eastern NCPBZ as a whole, has been under the influence of a single-phase of deformation since the Oligocene (Fig. 15B and C). Speed and Larue (1991) attributed the major structural features in the plate boundary zone (i.e., Puerto Rico trench, Mona Passage, Anegada Passage, etc.) to Neogene transtension with a component of N-S extension. The Speed and Larue (1991) transtensional model for the Puerto Rico trench as an extensional graben (Fig. 15B), has not been supported by subsequent studies, which consider the plate boundary to be transpressional (e.g., van Gestel et al., 1998; ten Brink and Lin, 2004; ten Brink et al., 2009).

Vogt et al. (1976) proposed a deformation model in which E-W extension is localized within Mona Passage to accommodate the motion of the PRVI microplate away from Hispaniola, which is tectonically-pinned by the Bahamas Platform. The Vogt et al. (1976) model (Fig. 15C) implies the presence of significant N-S oriented extensional structures within Mona Passage crust, such as the Mona, Cabo Rojo, and Yuma rifts. With the exception of Mona Canyon, which ends about $25 \mathrm{~km}$ north of Desecheo Ridge (Fig. 3A), there are no well-developed N-S oriented structural trends in Mona Passage visible on the bathymetry or seismic reflection data. Furthermore, there is little geophysical or seismological evidence to suggest the 


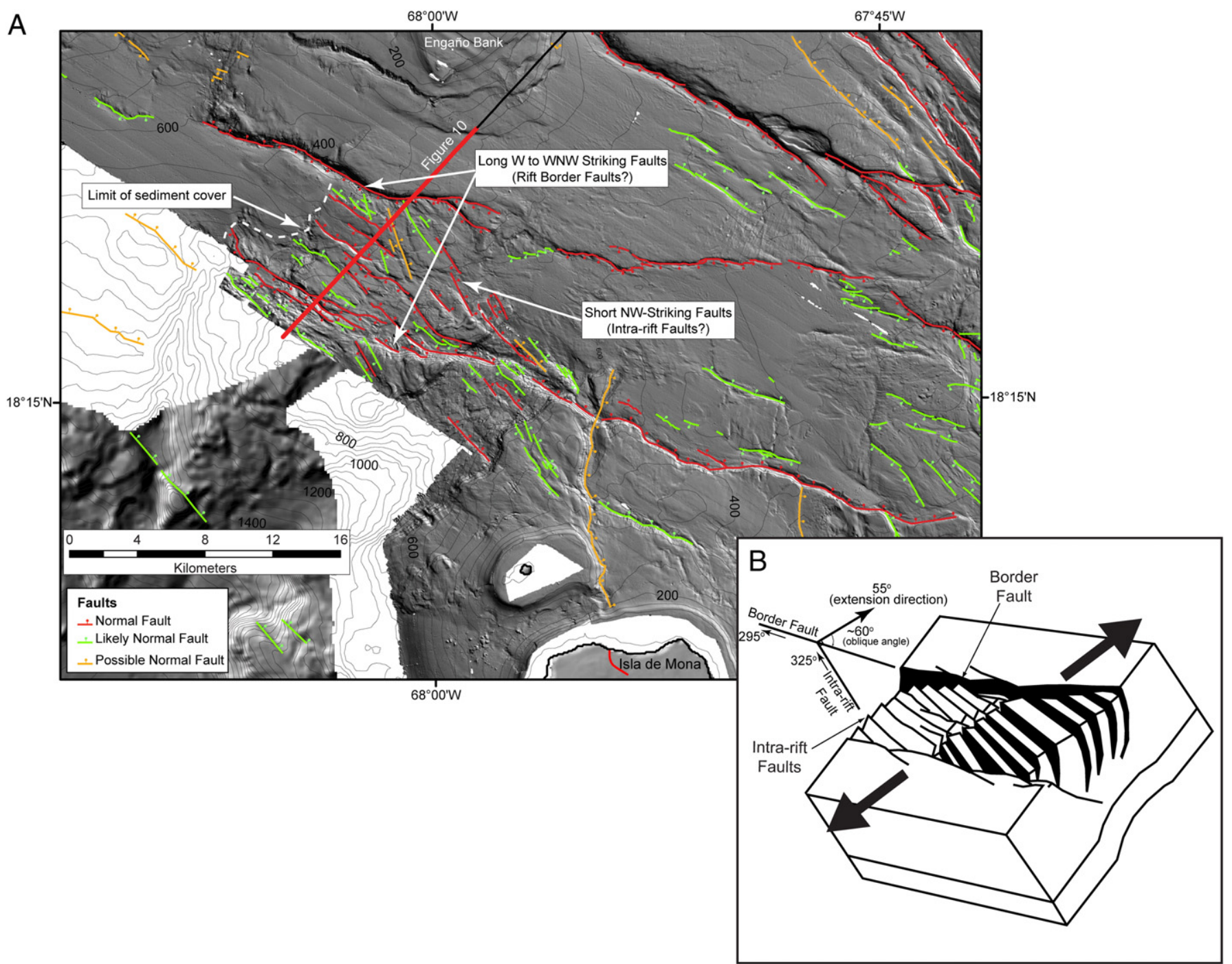

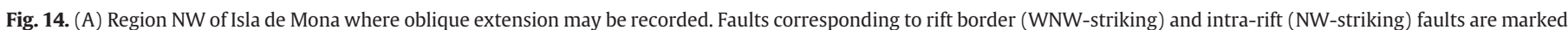

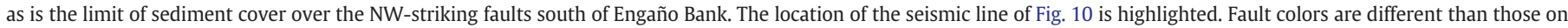

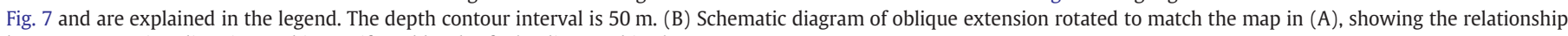
between extension direction and intra-rift and border faults discussed in the text.

Yuma and Cabo Rojo "rifts" are active extensional features, and Granja Bruna et al. (2009) observe no active N-S oriented structures influencing the Muertos Trough and accretionary wedge.

Another proposed single-phase extension model attributes a $25 \mathrm{~km}$-wide zone of normal faults in Mona Passage and Puerto Rico to extension at the crest of a $230-\mathrm{km}$-wide crustal arch or fold (bending-moment faulting; Fig. 15D; van Gestel et al., 1998, 1999; Grindlay et al., 2005; Hippolyte et al., 2005; Mann et al., 2005a,b), driven by $\mathrm{N}-\mathrm{S}$ compressive forces. The primary evidence used for the interpretation of the Puerto Rico-Virgin Islands island arc as a crustal arch is the variation in dip of the carbonate platform surrounding Puerto Rico and the Virgin Islands from N-dipping along the northern margin of the platform to S-dipping along the southern margin.

A bending model seems incompatible with a number of observations within Mona Passage and the overall tectonic environment of the region. Bending-moment extensional faults have been found only in a limited number of cases, almost all of which were a direct consequence of surface deformation following fault rupture (Philip and Meghraoui, 1983; Yeats, 1986). Formation of the bendingmoment faults at the crest of fault-related folds, which are at most a few kilometers wide, has been attributed to tension generated by lengthening of stiffer flexed layers on the convex side of a fold (Yeats,
1986). These faults are usually secondary and do not extend to significant depth. In contrast, the arch model of van Gestel et al. (1998) extends over a width of $230 \mathrm{~km}$ from the Puerto Rico trench to the Muertos Trough. The horizontal compressive stresses active along the NCPBZ and horizontal forces acting on the lithosphere in general, are likely too small to buckle rigid island arc lithosphere over a wavelength of more than $400 \mathrm{~km}$.

Furthermore, the primary evidence for arching of the eastern NCPBZ, the consistent seaward dipping nature of the carbonate platform on either side of Puerto Rico and the Virgin Islands, is poorly defined within Mona Passage (Fig. 16). The apparent dips of the carbonate layers vary in direction and angle and do not form a clear arch with a defined hinge. Although in places there is the appearance of a northward and southward seaward dip of the platform, it is most likely due to the well-developed block-faulting present throughout the passage, coupled with the collapse of the carbonate platform along its northern edge (ten Brink, 2005) and extensional strains at the hinterland of the Muertos thrust wedge (Granja Bruna et al., 2009).

5.2.2.3. Extension during rotation. Paleomagnetic results from prePliocene carbonate (Reid et al., 1991) and Cretaceous Eocene arc rocks (Fink and Harrison, 1972; Elston and Krushensky, 1983; Van 


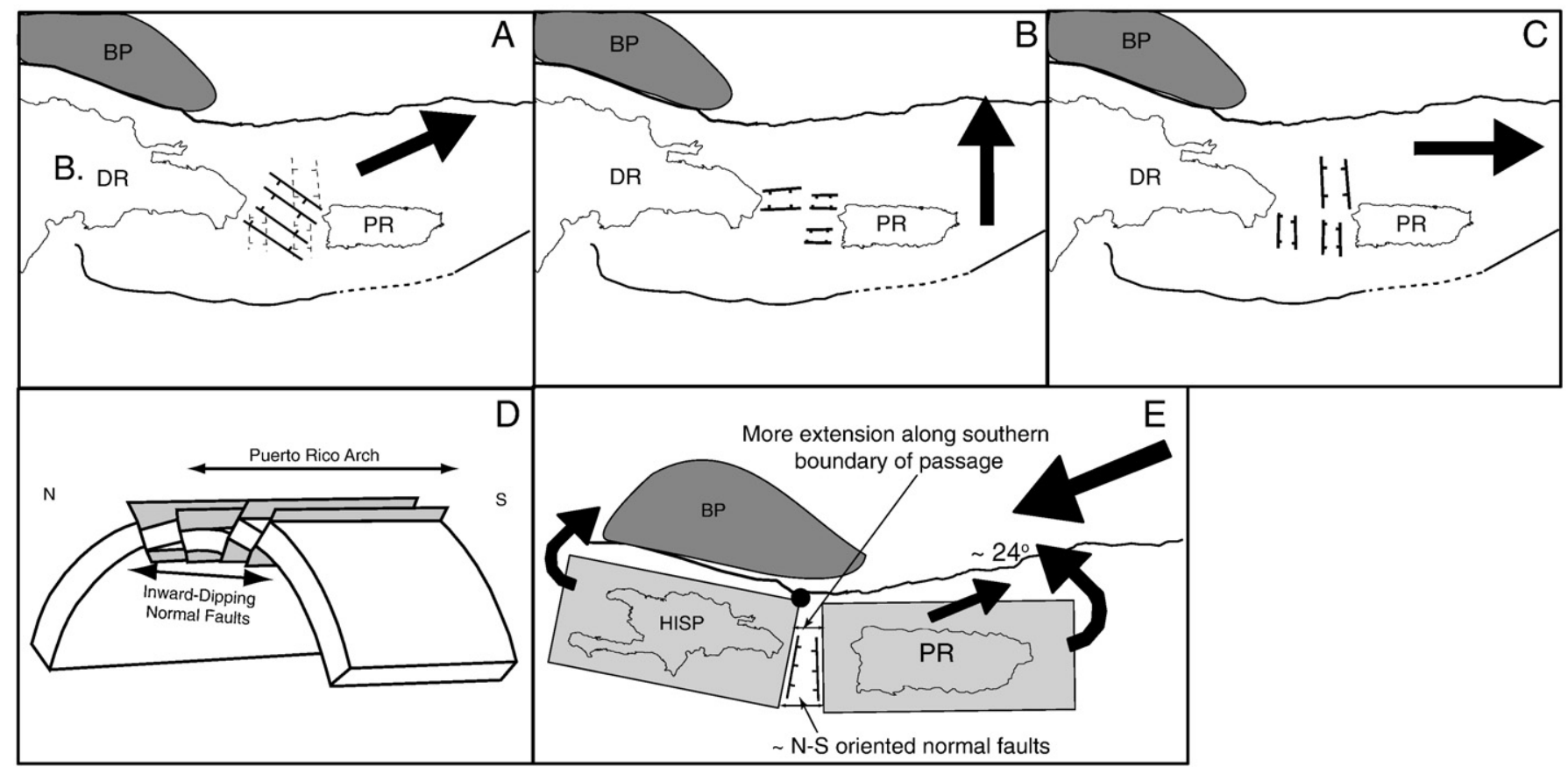

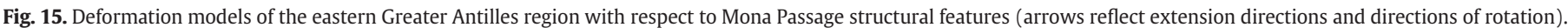

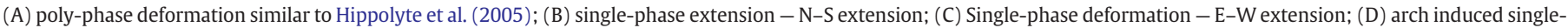

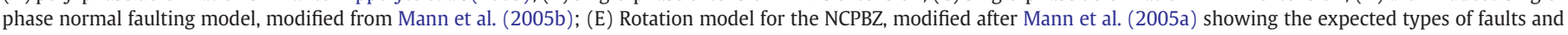
difference in the amount of extension of the northern Mona Passage boundary compared to the southern boundary.

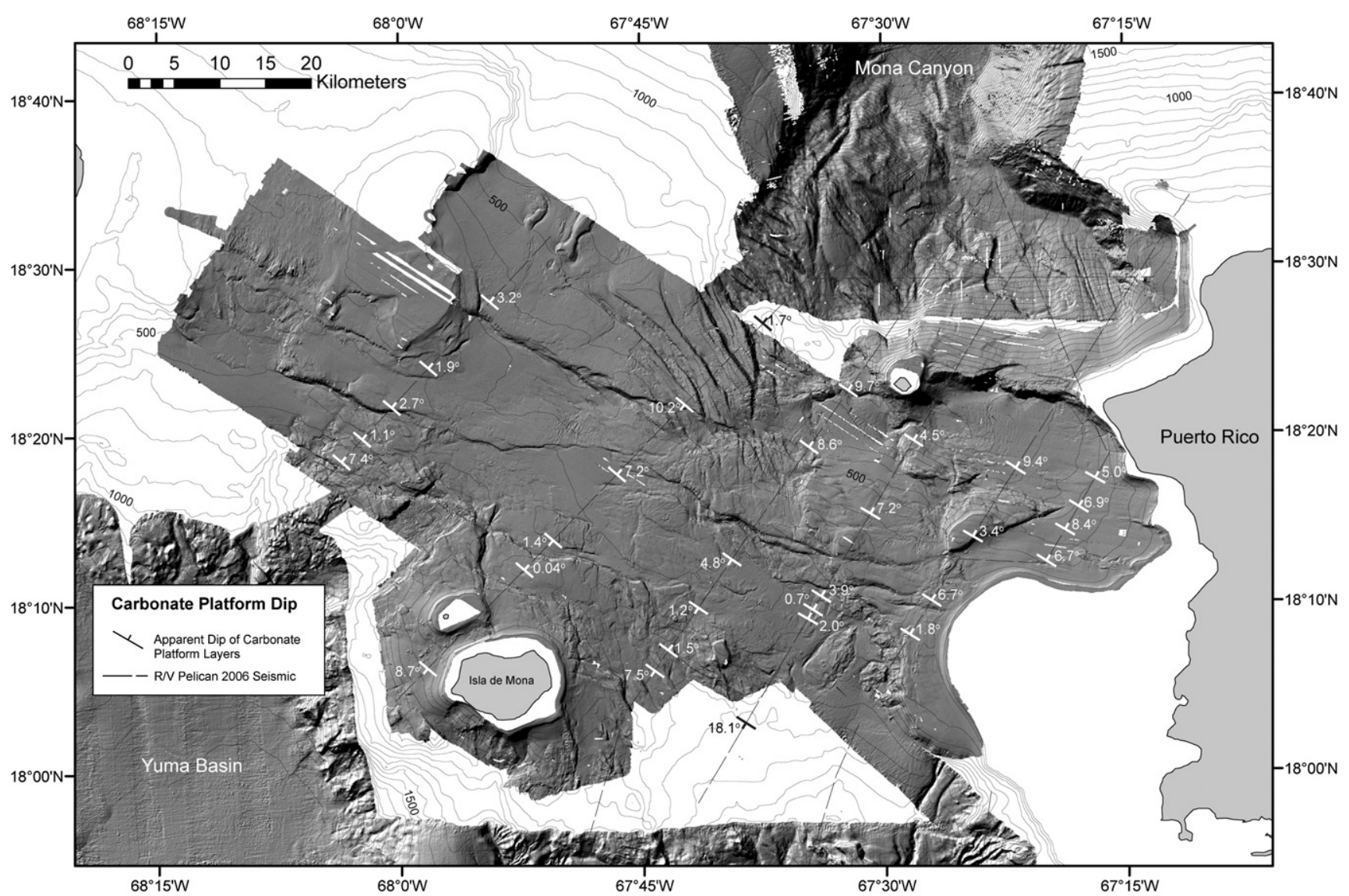

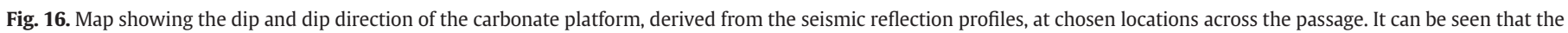
platform does not form a simple antiform or arch, but is rather influenced by local tectonic and gravitational processes. 
Fossen et al., 1989) suggest that Puerto Rico has undergone significant counter-clockwise (CCW) rotation in the post-Cretaceous. Counter-clockwise rotation of the PRVI microplate was used to explain extension in the Mona Passage (Fig. 15E) and elsewhere in the eastern NCPBZ (e.g., Schell and Tarr, 1978; Masson and Scanlon, 1991; Mann et al., 2005a). A CCW rotation model fits with a number of general observations, including compression in the Puerto Rico trench and western Muertos Trough, and extension in the Anegada Passage and Mona Canyon. However, paleomagnetic measurements from northern Puerto Rico indicate that the CCW rotation of the PRVI microplate ceased approximately $4 \mathrm{Ma}$ (Reid et al., 1991).

The recent GPS data summarized above indicate that a counterclockwise rotation model is incompatible with ongoing deformation in the western Puerto Rico and the Mona Passage. No clear rotation signal is currently seen in these GPS vectors as has been seen in several other regions worldwide (e.g., McCaffrey et al., 2000). Furthermore, if the extension recorded in Mona Passage is the result of the $24^{\circ}$ of rotation, two diagnostic features would be expected: significant development of $\mathrm{N}-\mathrm{S}$ oriented structures and greater extension along the southern boundary of the passage compared to the northern boundary (Fig. 15E). Neither of these diagnostic features is observed in the new geophysical data set.

\subsection{Earthquake hazard from Mona Passage}

Frequent low-magnitude seismicity $(M \leq 6)$ occurs from the surface down to depths over $200 \mathrm{~km}$ throughout the Greater Antilles between the Muertos trough and Puerto Rico trench at the latitude of
Mona Passage. The Greater Antilles crust in the eastern NCPBZ is likely no thicker than $30 \mathrm{~km}$ (Talwani et al., 1959; Jolly et al., 1998; ten Brink, 2005). At shallow depths ( $<15 \mathrm{~km})$, seismicity is focused in a broad band from southwestern Puerto Rico (predominantly the Lajas Valley) to the eastern Mona Passage, turning north into the Mona Canyon (Fig. 17). Shallow upper-crustal seismicity is largely absent within the passage west of Isla de Mona and in the eastern Dominican Republic, although this may be a function of limited station coverage west of Puerto Rico (Clinton et al., 2006). Four large earthquakes $(M>6.0)$ have occurred in the Mona Passage region during the last two centuries (Russo and Bareford, 1993; Doser et al., 2005). Just one of these, the M7.2 1918 Mona Canyon earthquake (Doser et al., 2005; Fig. 17), likely occurred within Mona Passage (Reid and Tabor, 1918; Lopez-Venegas et al., 2008), although the paucity of seismic stations at the time allows determination of the epicenter to within only about $50 \mathrm{~km}$ (E. Okal, pers. comm., 2008). Waveform modeling of the focal mechanism of this earthquake indicates normal-motion rupture along either a NE-striking, SE-dipping plane, or on a ENE-striking, NNWdipping plane (Doser et al., 2005). Although microseismicity is relatively intense adjacent to the west coast of Puerto Rico, the diffuse pattern of epicenters and few high magnitude earthquakes cannot provide accurate fault plane information. The seismic reflection data and bathymetry indicate that several fault strands in the Mayagüez basin may be currently active, and form part of a larger active fault system that extends onto Puerto Rico (Grindlay et al., 2005).

The January 12, $2010 \mathrm{M}_{\mathrm{w}} 7.0$ Haiti earthquake has shown that moderate intra-arc, earthquakes in the northeast Caribbean can have

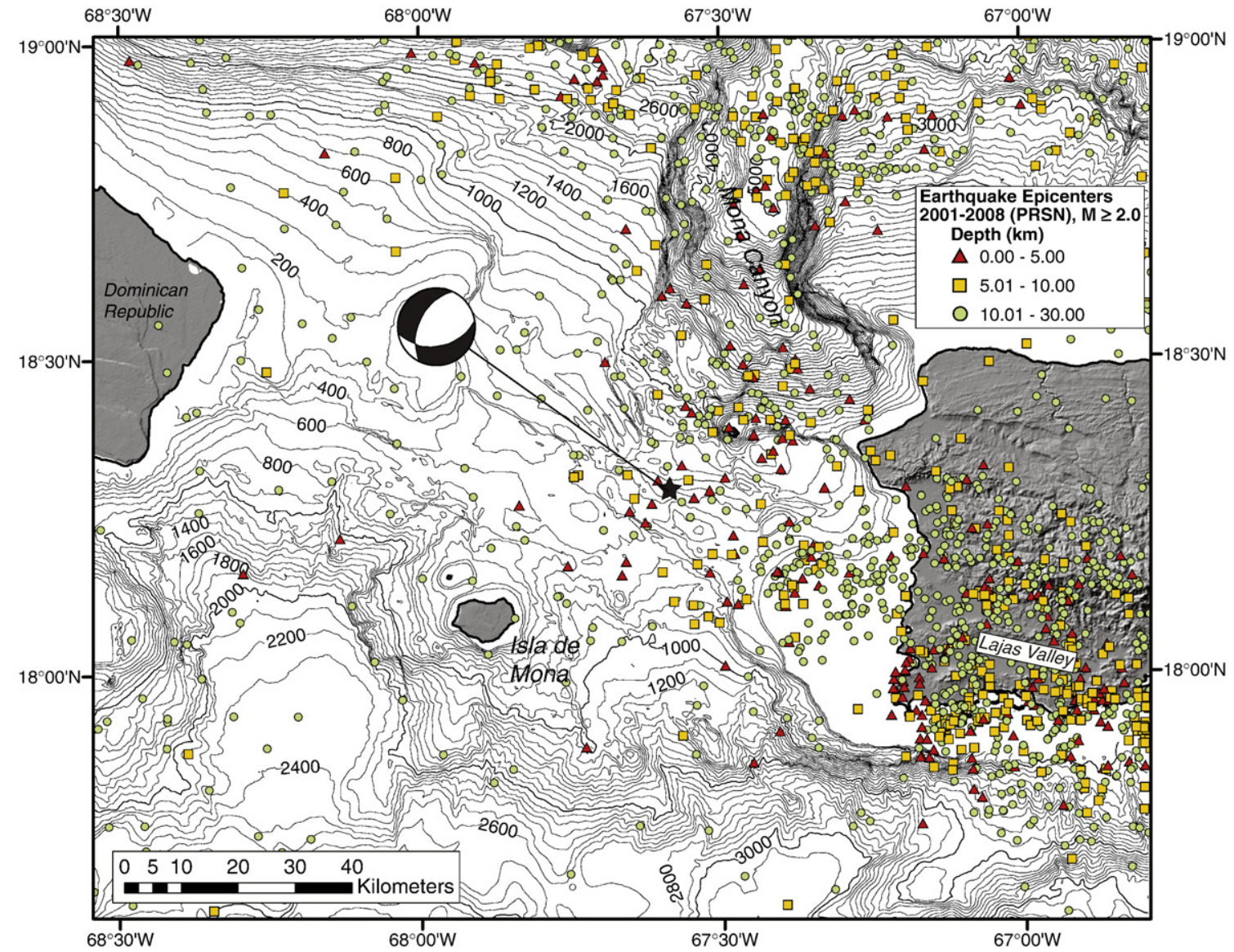

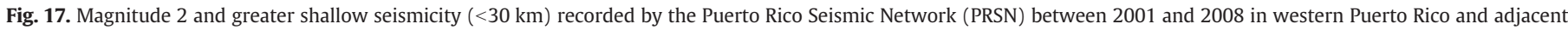

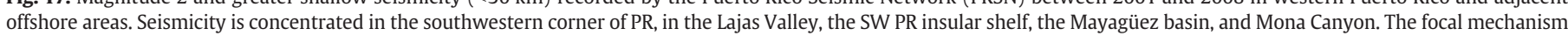
of the 1918 Mona Passage earthquake from Doser et al. (2005) is shown at the epicenter location determined by Russo and Bareford (1993). 
devastating effects. Using the empirical relationship between fault dimensions, displacement, and magnitude of Wells and Coppersmith (1994), estimates of potential earthquake magnitude can be made for two faults in the passage if they ruptured their entire lengths. The first fault (marked as 1 on Fig. 6), the Desecheo Island fault, from Punta Higuero to Desecheo Island is approximately $20 \mathrm{~km}$ long, and, assuming a conservative down-dip fault width of $15 \mathrm{~km}$ could generate an earthquake $\leq \mathrm{M}_{\mathrm{w}}$ 6.5. The second fault (marked as 2 on Fig. 6), is approximately $75 \mathrm{~km}$ long and, again assuming a width of $15 \mathrm{~km}$, could generate an earthquake $\leq \mathrm{M}_{\mathrm{w}} 7$. Both these hypothetical earthquakes could cause significant damage in Puerto Rico and Hispaniola similar to the 1918 earthquake.

\section{Conclusions}

This paper presents observations and discussions of diffuse extension within the northern Caribbean oceanic island arc. Mona Passage, between Puerto Rico and the Dominican Republic, is a zone of active, intra-arc oblique extension. Structural interpretations of the passage have previously been based on limited spatial data coverage, constrained in most cases to widely-spaced seismic reflection profiles. The combined interpretation of newly acquired multibeam bathymetry and seismic reflection profiles has revealed the complex morphologic and structural fabric of Mona Passage.

Deformation across Mona Passage as reflected by GPS (ENEdirected extension), is being accommodated by numerous normal faults with W to NNW strikes. Several major faults are identified that cross almost the entire width of the passage and, in some instances such as the Desecheo Ridge fault and faults within Mayagüez basin, may connect with faults identified on land in Puerto Rico. Although the kinematics of the deformation are still not completely resolved, the structural architecture within the passage based on the available data appears to be most compatible with an oblique extension model. Other proposed kinematic models such as single-phase extension with either $\mathrm{N}-\mathrm{S}$ or $\mathrm{E}-\mathrm{W}$ oriented structures, poly-phase extension, extension related to continued rotation of Puerto Rico, and arching-related faulting models are not supported by the structural interpretation. Because of the general absence of young sediment accumulation and fault piercing points, the actual amount of extension across the passage and the relative role and timing of Mona Passage, Mona Canyon, and other adjacent major tectonic features (e.g., Muertos Trough, Septentrional fault, etc.) in accommodating the extension cannot be adequately resolved. Within certain sections of Mona Passage, such as the Mayagüez basin/half-graben, there is evidence for more mature rift development and hence a greater level of extension. GPS data have large uncertainties, but across Mona Passage appear to indicate an ENE-directed extension, in accord with the $N 55^{\circ} \mathrm{E}$ extension direction deduced from the structural analysis.

Finally, Mona Passage and adjacent areas are associated with seismic activity and a history of damaging earthquakes, landslides, and tsunamis. Several faults within the passage, if they were to rupture along their entire length, could generate earthquakes with magnitudes on the order of $\mathrm{M}_{\mathrm{w}}$ 6.5-7.0. A better understanding of the rupture history and potential of active faults in the passage would improve seismic hazard assessment for the region.

\section{Acknowledgments}

We wish to thank the captains and crews of the NOAA Ship Nancy Foster and $R / V$ Pelican. We thank the science parties of both cruises (Brian Andrews, Wayne Baldwin, Roy Barkan, Emile Bergeron, Kelly Carignan, Chris Chamberlin, Bill Danforth, Claudia Flores, Barry Irwin, Alberto Lopez, Brooke McMahon, Thomas O'Brien, and Chuck Worley), Claudia Flores and Dave Foster for technical assistance and data processing, and Eric Calais for providing processed GPS data. Discussions with Jian Lin, Mark Behn, and Roger Buck helped focus some of our ideas. Reviews by Bill Dillon, Tom Pratt, and an anonymous reviewer greatly improved this manuscript. Any use of trade, product, or firm names is for descriptive purposes only and does not imply endorsement by the U.S. Government.

\section{References}

Allen, P.A., Allen, J.R., 1990. Basin Analysis: Principles and Applications. Blackwell, Oxford. $451 \mathrm{pp}$

Baker, V.R. 1978. Large-scale erosional and depositional features of the Channeled Scabland. In: Baker, V.R., Nummedal, D. (Eds.), The Channeled Scabland, National. Aeronautics and Space Administration, Washington, D.C. , pp. 81-115.

Bonini, M., Souriot, T., Boccaletti, M., Brun, J.-P., 1997. Successive orthogonal and oblique extension episodes in a rift zone; laboratory experiments with application to the Ethiopian Rift. Tectonics 16, 347-362.

Briggs, R.P., 1961. Geology of Kewanee Interamerican Oil Company test well number 4CRP, northern Puerto Rico. Oil and Gas possibilities of northern Puerto Rico, Puerto Rico Mining Commission, San Juan, pp. 1-23.

Briggs, R.P., 1964. Provisional geologic map of Puerto Rico and adjacent islands. Miscellaneous Geologic Investigations Map I-392. US Geological Survey 1, 240,000.

Briggs, R.P., Seiders, V.M., 1972. Geologic map of the Isla de Mona Quadrangle, Puerto Rico. Miscellaneous Geologic Investigations Map I-718. US Geological Survey 1, 20,000.

Busby, C.J., Bassett, K.N., 2007. Volcanic facies architecture of an intra-arc strike-slip basin, Santa Rita Mountains, Southern Arizona. Bulletin of Volcanology 70, 85-103.

Byrne, D.B., Suarez, G., McCann, W.R., 1985. Muertos trough subduction-microplate tectonics in the northern Caribbean. Nature 317, 420-421.

Calais, E., Mazabraud, Y., Mercier de Lépinay, B., Mann, P., Mattioli, G., Jansma, P., 2002. Strain partitioning and fault slip rates in the northeastern Caribbean from GPS measurements. Geophysical Research Letters 29, 1856. doi:10.1029/2002GL015397.

Chapple, W.M., Forsyth, D.W., 1979. Earthquakes and bending of plates at trenches. Journal of Geophysical Research 84, 6729-6749.

Clinton, J.F., Cua, G., Huerfano, V., von Hillebrandt-Andrade, C.G., Cruzardo, J.M., 2006. The current state of seismic monitoring in Puerto Rico. Seismological Research Letters 77, 532-543.

DeMets, C., Mattioli, G.S., Jansma, P.E., Rogers, R., Tenorios, C., Turner, H.L., 2007. Present motion and deformation of the Caribbean Plate; constraints from new GPS geodetic measurements from Honduras and Nicaragua. In: Mann, P. (Ed.), Geologic and Tectonic Development of the Caribbean Plate Boundary in Northern Central America: Geological Society of America Special Paper, 428, pp. 21-36.

Dewey, J.F., 1988. Extensional collapse of orogens. Tectonics 7, 1123-1139.

Doglioni, C., 1995. Geological remarks on the relationships between extension and convergent geodynamic settings. Tectonophysics 252, 253-267.

Dolan, J., Mann, P., de Zoeten, R., Heubeck, C., Shiroma, J., 1991. Sedimentological, stratigraphic, and tectonic synthesis of Eocene-Miocene sedimentary basins, Hispaniola and Puerto Rico. In: Mann, P., Draper, G., Lewis, J.F. (Eds.), Geologic and Tectonic Development of the North American-Caribbean Plate Boundary in Hispaniola: GSA Special Paper, 262, pp. 217-263.

Dolan, J., Mullins, H., Wald, D., 1998. Active tectonics of the northcentral Caribbean: oblique collision, strain partitioning, and opposing subducting slabs. In: Dolan, J., Mann, P. (Eds.), Active Strike-slip and Collisional Tectonics of the Northern Caribbean plate boundary zone: Geological Society of America Special Paper, 326, pp. 1-61.

Donnelly, T.W., 1989. Geologic history of the Caribbean and Central America. In: Bally, A.W., Palmer, A.R. (Eds.), An Overview, Geology of North America: A. Geological Society of America, Boulder, CO, pp. 299-321.

Doser, D.I, Rodriguez, C.M., Flores, C., 2005. Historical earthquakes of the Puerto RicoVirgin Islands region; 1915-1963. In: Mann, P. (Ed.), Active Tectonics and Seismic Hazards of Puerto Rico, the Virgin Islands, and Offshore Areas: Geological Society of America Special Paper, 385, pp. 103-114.

Edgar, N.T., Scanlon, K.M., 1987. Single-channel seismic-reflection profiles collected aboard R/V Powell, Cruises P-2-85, p-3-85, and P-4-85, in the near-shore waters around Puerto Rico and the Virgin Islands: U.S. Geological Survey Open-File Report, 87-147. 3 pp.

Elston, D.P., Krushensky, R.D., 1983. Puerto Rico: a translated terrane exotic to the Caribbean. Proceedings of the 10th Caribbean Geological Conference, p. 81

Ewing, M., Heezen, B.C., 1955. Puerto Rico trench topographic and geophysical data. Crust of the Earth: Geological Society of America Special Paper, 62, pp. 255-267.

Faerseth, R.B., Knudsen, B.-E., Liljedahl, T., Midbøe, P.S., Søderstrøm, B., 1997. Oblique rifting and sequential faulting in the Jurassic development of the northern North Sea. Journal of Structural Geology 19, 1285-1302.

Fink, L.K., Harrison, C.G.A., 1972. Paleomagnetic investigations of selected lava units on Puerto Rico. Proceedings of the 6th Caribbean Geological Conference, p. 379.

Ford, D.C., Williams, P., 2007. Karst Hydrogeology and Geomorphology. John Wiley \& Sons, West Sussex. 576 pp.

Frank, E.F., Wicks, C.M., Mylroie, J., Troester, J.W., Alexander Jr., E.C., Carew, J.L., 1998. Geology of Isla de Mona, Puerto Rico. Journal of Cave and Karst Studies 60, 69-72.

García Senz, J., Monthel, J., Díaz de Neira, J.A., Hernáiz Huerta, R.P., Escuder Viruete, J., Pérez Estaun, A., 1997. La estructura de la Cordillera Oriental de la República Dominicana. Boletín geológico y minero 118, 293-312.

Gardner, W.D., Glover, L.K., Hollister, C.D., 1980. Canyons off Northwest Puerto Rico; studies of their origin and maintenance with the nuclear research submarine NR-1. Marine Geology 37, 41-70.

Gawthorpe, R.G., Hurst, J.M., 1993. Transfer zones in extensional basins: their structural style and influence on drainage development and stratigraphy. Journal of the Geological Society of London 150,1137-1152. 
Geist, E.L., Childs, J.R., Scholl, D.W., 1988. The origin of summit basins of the Aleutian Ridge; implications for block rotation of an arc massif. Tectonics 2, 327-341.

Gonzalez, L.A., Ruiz, H.A., Taggart, B.E., Budd, A.F., Monell, V., 1997. Geology of Isla de Mona, Puerto Rico. In: Vacher, H.L., Wuinn, T. (Eds.), Geology and Hydrogeology of Carbonate Islands: Developments in Sedimentology, 54, pp. 327-358.

Granja Bruna, J.L., ten Brink, U.S., Carbo-Gorosabel, A., Munoz-Martin, A., Gomez Ballesteros, M., 2009. Morphotectonics of central Muertos thrust belt and Muertos Trough (northeast Caribbean). Marine Geology 263, 7-33.

Grindlay, N.R., Abrams, L.J., Del Greco, L., Mann, P., 2005. Toward an integrated understanding of Holocene fault activity in western Puerto Rico; constraints from high-resolution seismic and sidescan sonar data. In: Mann, P. (Ed.), Active Tectonics and Seismic Hazards of Puerto Rico, the Virgin Islands, and Offshore Areas: Geological Society of America Special Paper, 385, pp. 139-160.

Heezen, B.C., Nesteroff, W.D., Rawson, M., Freeman-Lynde, R.P., 1985. Visual evidence for subduction in the western Puerto Rico Trench. Géodynamique des Caraïbes Symposium, Paris 5-8 février: Éditions Technip, 27, pp. 287-304.

Hippolyte, J.-.C., Mann, P., Grindlay, N.R., 2005. Geologic evidence for the prolongation of active normal faults of the Mona rift into northwestern Puerto Rico. In: Mann, P. (Ed.), Active Tectonics and Seismic Hazards of Puerto Rico, the Virgin Islands, and Offshore Areas: Geological Society of America Special Paper, 385, pp. 161-171.

Jansma, P.E., Mattioli, G.S., 2005. GPS results from Puerto Rico and the Virgin Islands; constraints on tectonic setting and rates of active faulting. In: Mann, P. (Ed.), Active Tectonics and Seismic Hazards of Puerto Rico, the Virgin Islands, and Offshore Areas: Geological Society of America Special Paper, 385, pp. 13-30.

Jansma, P.E., Mattioli, G.S., Lopez, A., DeMets, C., Dixon, T.H., Mann, P., Calais, E., 2000. Neotectonics of Puerto Rico and the Virgin Islands, northeastern Caribbean, from GPS geodesy. Tectonics 19, 1021-1037.

Jolly, W.T., Lidiak, E.G., Schelleckens, H.S., Santos, S., 1998. Volcanism, tectonics, and stratigraphic correlations in Puerto Rico. In: Lidiak, E.G., Larue, D.K. (Eds.), Tectonics and Geochemistry of the Northeast Caribbean: Geological Society of America, Special Paper, 322, pp. 1-34.

Kaye, C.A., 1959. Geology of Isla Mona, Puerto Rico, and notes on age of Mona Passage. U. S. Geological Survey Professional Paper 317C, 141-178.

Kington, J.D., Goodliffe, A.M., 2008. Plate motions and continental extension at the rifting to spreading transition in Woodlark Basin, Papua New Guinea: can oceanic plate kinematics be extended into continental rifts. Tectonophysics 458, 82-95.

Larue, D.K., Berrong, B., 1991. Cross section through the Toa Baja drillsite; evidence for northward change in late Eocene deformation intensity. Geophysical Research Letters $18,561-564$

Larue, D.K., Torrini Jr., R., Smith, A.L., Joyce, J., 1998. North Coast Tertiary basin of Puerto Rico: from arc basin to carbonate platform to arc-massif slope. In: Lidiak, E.G., Larue, D.K. (Eds.), Tectonics and Geochemistry of the Northeast Caribbean: Geological Society of America, Special Paper, 322, pp. 155-176.

Lopez-Venegas, A.M., ten Brink, U.S., Geist, E.L., 2008. Submarine landslide as the source for the October 11, 1918 Mona Passage tsunami: observations and modeling. Marine Geology 254, 35-46.

Manaker, D.M., Calais, E., Freed, A.M., Ali, S.T., Przybylski, P., Mattioli, G., Jansma, P., Prépetit, C., de Chabalier, J.B., 2008. Interseismic plate coupling and strain partitioning in the Northeastern Caribbean. Geophysical Journal International 174, 889-903.

Mann, P., Burke, K., 1990. Transverse intra-arc rifting; Palaeogene Wagwater Belt, Jamaica. Marine and Petroleum Geology 7, 410-427.

Mann, P., Taylor, F.W., Edwards, R.L., Kuc, T., 1995. Actively evolving microplate formation by oblique collision and sideways motion along strike-slip faults: an example from the northeastern Caribbean plate margin. Tectonophysics 246, $1-69$.

Mann, P., Calais, E., Ruegg, J.-C., DeMets, C., Jansma, P.E., Mattioli, G.S., 2002. Oblique collision in the northeastern Caribbean from GPS measurements and geological observations. Tectonics 21. doi:10.1029/2001TC001304.

Mann, P., Hippolyte, J.-C., Grindlay, N.R., Abrams, L.J., 2005a. Neotectonics of southern Puerto Rico and its offshore margin; active tectonics and seismic hazards of Puerto Rico, the Virgin Islands, and offshore areas. In: Mann, P. (Ed.), Active Tectonics and Seismic Hazards of Puerto Rico, The Virgin Islands, and Offshore Areas: Geological Society of America Special Paper, 385, pp. 173-214.

Mann, P., Prentice, C.S., Hippolyte, J.-C., Grindlay, N.R., Abrams, L.J., Lao-Davila, D., 2005b. Reconnaissance study of late Quaternary faulting along Cerro Goden fault zone, western Puerto Rico. In: Mann, P. (Ed.), Active Tectonics and Seismic Hazards of Puerto Rico, the Virgin Islands, and Offshore Areas: Geological Society of America Special Paper, 385, pp. 115-137.

Masson, D.G., Scanlon, K.M., 1991. The neotectonic setting of Puerto Rico. Geological Society of America 103, 144-154

McAllister, E., Cann, J., Spencer, S., 1995. The evolution of crustal deformation in an oceanic extensional environment. Journal of Structural Geology 17, 183-199.

McCaffrey, R., Johnson, C.K., Zwick, P.C., Long, M.D., Goldfinger, C., Nabelek, J.L., Smith, C., 2000. Rotation and plate locking along the southern Cascadia subduction zone. Geophysical Research Letters 21, 3117-3120.

McClay, K.R., White, M.J., 1995. Analogue modelling of orthogonal and oblique rifting. Marine and Petroleum Geology 12,137-151.

McClay, K.R., Dooley, T., Whitehouse, P., Mills, M., 2002. 4-D evolution of rift systems: insights from scaled physical models. American Association of Petroleum Geologists Bulletin 86, 935-959.
Mercado, A., McCann, W., 1998. Numerical simulation of the 1918 Puerto Rico tsunami. Natural Hazards 18, 57-76.

Mondziel, S.A., Grindlay, N.R., Mann, P., Escalona, A., 2006. Multi-channel seismic images of Neogene rifting in the northern Mona Passage between Puerto Rico and Hispaniola. Eos Trans. AGU, 87 (52), Fall Meet. Suppl., Abstract T43D-1679.

Monroe, W.H., 1980. Geology of the middle Tertiary formations of Puerto Rico. U.S Geological Survey Professional Paper, 953. 93 pp.

Morley, C.K., Cunningham, S.M., Harper, R.M., Wescott, W.A., 1992. Geology and geophysics of the Rukwa Rift, East Africa. Tectonics 11, 69-81.

Moussa, M.T., Seiglie, G.A., Meyerhoff, A.A., Taner, I., 1987. The Quebradillas Limestone (Miocene-Pliocene), northern Puerto Rico, and tectonics of the northeastern Caribbean margin. Geological Society of America Bulletin 99, 427-439.

Nagle, F., Erlich, R.N., Canovi, C.J., 1978. Caribbean dredge haul compilation: summary and implications. Transactions of the 8th Caribbean Geological Conference: Geologie en Minjbouw, 57, pp. 267-270.

Philip, H., Meghraoui, M., 1983. Structural analysis and interpretation of the surface deformations of the El Asnam earthquake of October 10, 1980. Tectonics 2, 17-49.

Pindell, J.L., Barrett, S.F., 1990. Geological evolution of the Caribbean region; a plate tectonic perspective. In: Dengo, G., Case, J.E. (Eds.), The Caribbean, Volume H, Decade of North American Geology. Geological Society of America, Boulder, CO, pp. 404-431.

Reid, H.F., Tabor, S., 1919. The Porto Rico earthquakes of October-November, 1918 Bulletin of the Seismological Society of America 9, 95-127.

Reid, J.A., Plumley, P.W., Schellekens, J.H., 1991. Paleomagnetic evidence for late Miocene counterclockwise rotation of North Coast carbonate sequence, Puerto Rico. Geophysical Research Letters 18, 565-568.

Rodriguez, R.W., Trumbull, J.V.A., Dillon, W.P., 1977. Marine geologic map of Isla de Mona area, Puerto Rico. Miscellaneous Investigation Series Map I-1063: U.S. Geological Survey, 1, p. 40,000.

Royden, L.H., 1993. The tectonic expression slab pull at continental convergent boundaries. Tectonics 12, 303-325.

Ruiz, H.M., 1993. Sedimentology and diagenesis of Isla de Mona, Puerto Rico. M. S thesis, University of Iowa, Iowa City, 86pp.

Russo, R.M., Bareford, C., 1993. Historical Seismicity of the Caribbean Region, 1933-1963. Caribbean Conference on Volcanism, Seismicity and Earthquake Engineering. University of the West Indies, Trinidad.

Schell, B.A., Tarr, A.C., 1978. Plate tectonics of the northeastern Caribbean Sea region. In: MacGillavry, H.J., Beets, D.J. (Eds.), Geologie en Mijnbouw: Netherlands Journal of Geosciences, pp. 319-324.

Seiders, V.M., Briggs, R.P., Glover, L., 1972. Geology of Isla Desecheo, Puerto Rico, with notes on the Great Southern Puerto Rico Fault Zone and Quaternary stillstands of the sea. U.S. Geological Survey Professional Paper, 739. 22 pp.

Speed, R., Larue, D.K., 1991. Extension and transtension in the plate boundary zone of the northeastern Caribbean. Geophysical Research Letters 18, 573-576.

Suter, M., Quintero-Legorreta, O., Lopez-Martinez, M., Aguirre-Diaz, G., Farrar, E., 1995 The Acambay Graben; active intraarc extension in the Trans-Mexican volcanic belt, Mexico. Tectonics 14, 1245-1262.

Talwani, M., Sutton, G.H., Lamar Worzel, J., 1959. A crustal section across the Puerto Rico Trench. Journal of Geophysical Research 64, 1545-1555.

ten Brink, U., 2005. Vertical motions of the Puerto Rico Trench and Puerto Rico and their cause. Journal of Geophysical Research 110. doi:10.1029/2004JB003459.

ten Brink, U., Lin, J., 2004. Stress interaction between subduction earthquakes and forearc strike-slip faults; modeling and application to the northern Caribbean plate boundary. Journal of Geophysical Research 109. doi:10.1029/2004JB003031.

ten Brink, U.S., Marshak, S., Granja, J.L., 2009. Bivergent thrust wedges surrounding island arcs: insights from observations and sandbox models of the northeastern Caribbean plate. Geological Society of America Bulletin 121, 1522-1536.

Tron, V., Brun, J.-P., 1991. Experiments on oblique rifting in brittle-ductile systems. Tectonophysics $188,71-84$.

van Fossen, M.C., Channell, J.E.T., Schellekens, J.H., 1989. Paleomagnetic evidence for tertiary anticlockwise rotation in southwest Puerto Rico. Geophysical Research Letters 16, 819-822.

van Gestel, J., Mann, P., Dolan, J.F., Grindlay, N.R., 1998. Structure and tectonics of the upper Cenozoic Puerto Rico-Virgin Islands carbonate platform as determined from seismic reflection studies. Journal of Geophysical Research 103, 30505-30530.

van Gestel, J.P., Mann, P., Grindlay, N.R., Dolan, J.F., 1999. Three-phase tectonic evolution of the northern margin of Puerto Rico as inferred from an integration of seismic reflection, well, and outcrop data. Marine Geology 161, 257-286.

Vogt, P.R., Lowrie, A., Bracey, D.R., Hey, R.N., 1976. Subduction of aseismic oceanic ridges: effects on shape, seismicity, and other characteristics of consuming plate boundaries. Geological Society of America Special Paper 17259 pp..

Walsh, J., Watterson, J., Yielding, G., 1991. The importance of small-scale faulting in regional extension. Nature 351, 391-393.

Wells, D.L., Coppersmith, J.J., 1994. New empirical relationships among magnitude, rupture length, rupture width, rupture area, and surface displacement. Bulletin of the Seismological Society of America 84, 974-1002.

Wessel, J.K., Fryer, P., Wessel, P., Taylor, B., 1994. Extension in the northern Mariana inner forearc. Journal of Geophysical Research 99, 15,181-15, 203.

Withjack, M.O., Jamison, W.R., 1986. Deformation produced by oblique rifting. Tectonophysics 126, 99-124.

Yeats, R.S., 1986. Active faults related to folding. In: Wallace, R.E. (Ed.), Active Tectonics. Studies in Geophysics, National Academy Press, Washington, D.C., pp. 45-62. 